\title{
Sequence stratigraphy and the interpretation of Neoproterozoic earth history
}

\author{
Nicholas Christie-Blick ${ }^{\mathrm{a}, *}$, Ian A. Dyson ${ }^{\mathrm{b}}$, C.C. von der Borch ${ }^{\mathrm{b}}$ \\ a Department of Geological Sciences and Lamont-Doherty Earth Observatory of Columbia University, Palisades, NY IO964, USA \\ b School of Earth Sciences, Flinders University of South Australia, G.P.O. Box 2100, Adelaide, S.A. 5001, Australia
}

Received 18 October 1993; revised version accepted 13 October 1994

\begin{abstract}
The application of sequence stratigraphy to Neoproterozoic successions is important for improving the resolution of timecorrelation within individual sedimentary basins and potentially at a global scale. The methodology is illustrated in this paper by reference to two contrasting examples from the Flinders Ranges (Adelaide geosyncline) of South Australia, where the younger part of the Neoproterozoic to earliest Cambrian succession ( $\sim 770 \mathrm{Ma}$ to $\sim 540 \mathrm{Ma}$ ) has been divided into thirteen unconformity-bounded depositional sequences. One of the most prominent sequence boundaries, at or near the base of the Wonoka Formation, is characterized by a series of buried canyons as much as $1 \mathrm{~km}$ deep. High-resolution sequence-stratigraphic studies at Umberatana syncline continue to support the view that the canyons were cut subaerially and filled by fluvial and shallow-water sediments. In contrast to the Wonoka canyons, sequence boundaries interpreted at the base of the Nuccaleena Formation/Seacliff Sandstone and near the top of the ABC Range Quartzite are relatively subtle, with only limited evidence for erosion and valley incision. Four sequence boundaries, at the level of the Sturtian and Marinoan (Varanger?) glacial deposits and in the vicinity of the Precambrian-Cambrian boundary, are thought to correlate with surfaces in the Amadeus basin of central Australia. Other prominent sequence boundaries, including the Wonoka canyons and surfaces within the upper part of the Wonoka Formation and at the base of the Ediacara Member of the Rawnsley Quartzite, correspond with a relatively condensed section in the Amadeus basin, and their lateral persistence beyond the Adelaide geosyncline is therefore difficult to evaluate. Given the lack of precision in biostratigraphy and isotope geochemistry in Neoproterozoic rocks, and in a marked departure from Phanerozoic practice, we recommend placement of a terminal Proterozoic GSSP at a sequence boundary. A prime candidate in Australia is the sequence boundary at the base of the Nuccaleena Formation/Seacliff Sandstone, immediately above the Marinoan glacial rocks in the Adelaide geosyncline, and its likely correlative at or near the base of the Gaylad Sandstone in the Amadeus basin.
\end{abstract}

\section{Introduction}

The stratigraphic record is fundamentally discontinuous, and this has profound implications for the interpretation of Neoproterozoic earth history (Christie-Blick and Levy, 1985; Lindsay, 1987; Christie-Blick et al., 1988; von der Borch et al., 1988).

\footnotetext{
* Corresponding author.
}

Although approximate continuity has long been the practical paradigm in Neoproterozoic studies (e.g., Young, 1979; Christie-Blick, 1982; Preiss, 1987; Shanker and Mathur, 1992; Siedlecka and Roberts, 1992; Xing, 1992), concordant strata are not necessarily conformable. Instead, subtle but objectively identifiable unconformities are commonly present, especially in successions for which the average rate of 
sediment accumulation is low ( $<10 \mathrm{~m} / \mathrm{m} . \mathrm{y}$.$) , and in$ some cases they represent significant breaks in sedimentation. Unconformities are more likely to be overlooked in strata of Neoproterozoic age than in Phanerozoic counterparts owing to poor biostratigraphic resolution and the need to rely on physical stratigraphic evidence for breaks, evidence that is commonly only locally developed. Most relevant to efforts at integrating diverse stratigraphic signals at a global scale is the fact that failure to recognize cryptic unconformities may result in the mistaken perception of synchrony and hence in the miscorrelation of biostratigraphic, geochemical, paleomagnetic or other "events" that are in reality of different ages.

The study of sedimentary successions in terms of repetitively arranged facies and associated discontinuities has become known as sequence stratigraphy (Vail, 1987; Van Wagoner et al., 1988, 1990; Christie-Blick, 1991a; Christie-Blick and Driscoll, 1995). It is a technique that can be traced back to the work of Sloss et al. (1949), Sloss (1950, 1963) and Wheeler (1958), but which became widely employed only after the development of seismic stratigraphy, the stratigraphic interpretation of seismic reflection profiles (Vail et al., 1977, 1984, 1991; Berg and Woolverton, 1985; Cross and Lessenger, 1988; Sloss, 1988; Christie-Blick et al., 1990a; Van Wagoner et al., 1990; Vail, 1992; ChristieBlick and Driscoll, 1995). Amongst the earliest attempts to apply sequence stratigraphy to Neoproterozoic and Early Cambrian geology were studies begun in 1984 in the western United States (Christie-Blick and Levy, 1985, 1989; Link et al., 1987; Christie-Blick et al., 1988; Levy, 1991; Levy and Christie-Blick, 1991; Levy et al., 1994), and at about the same time in the Flinders Ranges of South Australia (Christie-Blick and von der Borch, 1985; von der Borch et al., 1986, 1988, 1989; Christie-Blick et al., 1988, 1990b; Gravestock and Hibburt, 1991; Mount and McDonald, 1992; DiBona and von der Borch, 1993) and in the Amadeus basin of central Australia (Lindsay, 1987, 1993; Lindsay and Korsch, 1989, 1991). Since the mid1980s, sequence stratigraphy has become increasingly applied in Proterozoic and Cambrian geology in Canada (Grotzinger et al., 1989; Bowring and Grotzinger, 1992; Myrow and Hiscott, 1993; Myrow, 1995), China (Qiao Xiufu et al., 1991; Wang Chengshu, pers. commun., 1993), Siberia (Pelechaty and Grotzinger,
1993) and Africa (Deynoux et al., 1991; Saylor et al. 1995).

The purpose of this paper is to review how concepts of sequence stratigraphy can be applied to Neoproterozoic successions, to draw attention to some practical difficulties of the technique, and to discuss implications for an emerging global framework for Neoproterozoic time. Examples are drawn primarily from recent work in the Flinders Ranges (Adelaide geosyncline) of South Australia, which represents one of the areas being considered for defining a Global Stratotype Section and Point (GSSP) for the base of a new terminal Proterozoic system.

\section{Sequence stratigraphy in Neoproterozoic successions}

\subsection{Conceptual framework}

The basic concepts and methodology of sequence stratigraphy are described in numerous articles, especially Haq et al. (1987), Vail (1987), Baum and Vail (1988), Loutit et al. (1988), Posamentier and Vail (1988), Posamentier et al. (1988), Sarg (1988), Van Wagoner et al. (1988, 1990), Christie-Blick (1991a), Haq (1991), Mitchum and Van Wagoner (1991), Vail et al. (1991), Posamentier and James (1993) and Christie-Blick and Driscoll (1995). The fundamental unit is the "sequence", which is defined as a relatively conformable succession of genetically related strata bounded by unconformities and their correlative conformities (Fig. 1; Mitchum, 1977; Van Wagoner et al., 1988, 1990; Christie-Blick, 1991a). In this context, the term unconformity is restricted to those surfaces that are related (or are inferred to be related) at least locally to the lowering of depositional base level, and hence to subaerial erosion or bypassing (Vail et al., 1984; Van Wagoner et al., 1988). However, the term includes many surfaces that in classical stratigraphy would be described as disconformities or paraconformities (Dunbar and Rodgers, 1957) or ignored as insignificant. Sequences are composed of systematically arranged "parasequences" - successions of genetically related beds bounded by flooding surfaces and their correlative surfaces. Parasequences are most easily recognized in nearshore deposits, where they tend to shoal upwards. Sequences are also divisible into 


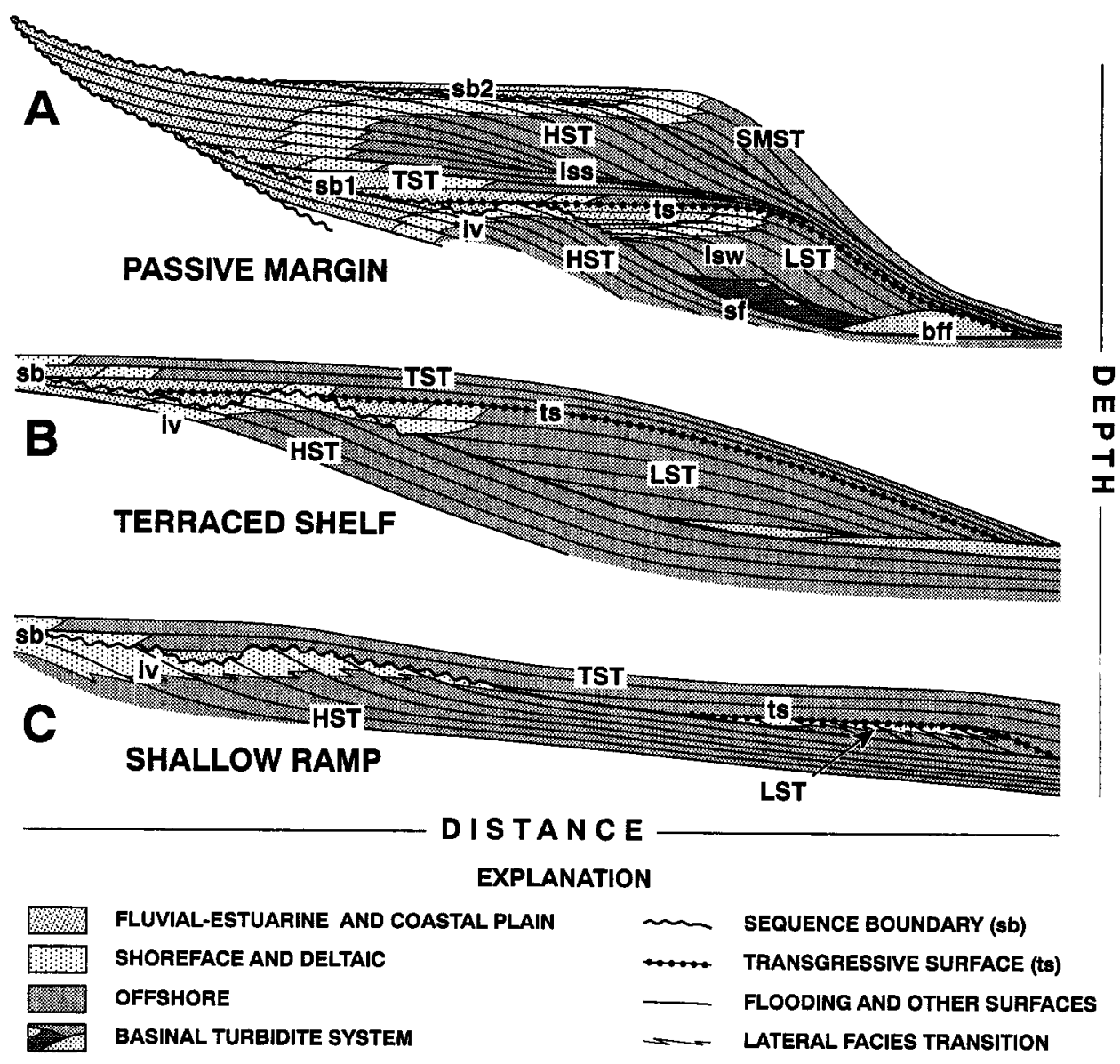

Fig. 1. Conceptual cross-sections showing stratal geometry, systems tracts and the distribution of siliciclastic facies within unconformity-bounded depositional sequences (modified from Vail, 1987; Christie-Blick, 1991a; Posamentier et al., 1992; Walker and Plint, 1992). The three examples depicted, passive margin (A), terraced shelf (B), and shallow ramp (C), represent depositional settings with progressively less physiographic differentiation and at progressively decreasing scale. Systems tracts: $S M S T=$ shelf $\operatorname{margin} ; H S T=$ highstand; $T S T=$ transgressive; $L S T=$ lowstand. Sequence boundaries $(\mathrm{sb}): s b 2=$ type $2 ; s b 1=$ type 1 . Other abbreviations: $i s s=$ interval of sediment starvation; $t s=$ transgressive surface; $i v=$ incised valley; $l s w=$ lowstand prograding wedge; $s f=$ slope fan; $b f f=$ basin floor fan. Note that in the seismic stratigraphic literature the term submarine fan includes a variety of turbidite systems and sediment-gravity-flow deposits that are not necessarily fan-shaped.

"systems tracts" associations of facies composed of one or more parasequences, and they are defined on the basis of stratigraphic position and according to whether successive parasequences tend to shoal or deepen upwards overall (Fig. 1). Sequences and parasequences overlap in scale and in some cases their bounding surfaces coincide. As a practical matter, successions are divided as far as possible into sequences, and parasequence terminology is used when objective recog- nition of laterally persistent sequence boundaries is no longer possible.

Much of the early work in seismic and sequence stratigraphy was done in intracratonic and passive-margin settings characterized by relatively simple patterns of subsidence, and in many cases by a well developed shelf break. It has become increasingly clear that in detail sequences are of variable character and origin, according to tectonic setting (and subsidence history), 
physiography of the depositional site, sediment type, terrigenous flux, and whether or not sedimentation was modulated by glacial-eustasy (Vail, 1987; Sarg, 1988; Van Wagoner et al., 1990; Reynolds et al., 1991; Greenlee et al., 1992; Walker and Plint, 1992; Holmes and Christie-Blick, 1993; Christie-Blick and Driscoll, 1995; Driscoll et al., 1995). Most preserved Neoproterozoic deposits accumulated in extensional, foreland, other intracratonic and passive-margin settings characterized by shallow depositional ramps lacking pronounced breaks in slope. These deposits correspond to the parts of Figs. 1A and $1 \mathrm{~B}$ landward of the shelf break and/or to the shallow ramp illustrated in Fig. 1C. 'Deep-water' syn-rift and early post-rift deposits and carbonate platforms with steep seaward margins, described by Preiss (1987), Ross (1991) and Myrow (1995) from the Neoproterozoic of North America and South Australia, are exceptions.

\subsection{Recognition of sequence boundaries in Neoproterozoic successions}

Objective recognition and tracing of sequence boundaries is fundamental to reliable sequence-stratigraphic interpretation. To the extent that Neoproterozoic rocks pose special difficulties, the following are some practical suggestions.

(1) At an outcrop scale, the most useful criteria for the interpretation of a sequence boundary are: $(a)$ evidence for subaerial exposure and/or erosion (incised valleys); $(b)$ the presence of a facies discontinuity characterized by abrupt upward shoaling; and (c) a change in the stacking pattern of parasequences from a forestepping to a backstepping motif (Van Wagoner et al., 1990; Christie-Blick, 1991a). Note that evidence for exposure (e.g., a paleosol or vadose diagenesis) is not sufficient if it cannot be demonstrated that base level was lowered during development of the surface, and evidence for erosion does not by itself require subaerial exposure. Also, in the absence of suitable paleontological indicators, the interpretation of a facies discontinuity must depend entirely on physical sedimentological evidence, which introduces additional uncertainties. Where a flooding surface amalgamates with a sequence boundary (e.g., Fig. 1C), the prior history of the surface may be obscured. However, if in examining a section parasequences begin to backstep before an obvious sequence boundary is encoun- tered, it is worth going back down section a few metres to tens of metres and walking laterally. We have discovered several previously undocumented examples of incised valleys in this way.

(2) Incised valleys differ from fluvial or distributary channels in a normal shoaling-upward succession (Van Wagoner et al., 1990). Valleys are associated with a mappable surface, and their erosional relief is commonly greater than that of channels within the same succession. They are typically filled by a combination of fluvial and estuarine deposits, which in many Proterozoic examples are unusually coarse-grained and compositionally distinct from strata below the valley (Levy et al., 1994). Valley walls in some cases exhibit evidence for a hiatus in sedimentation between erosion and subsequent deposition (e.g., evidence that the wallrocks were already consolidated or lithified, or the presence of paleosols).

(3) Sequences and sequence boundaries are most easily defined where shallow-marine and non-marine sediments intertongue, near the seaward margins of carbonate platforms, and where sequences and/or parasequences are strongly forestepping (regressive). In contrast, interpretation is commonly difficult in successions lacking significant facies variation, and where the overall motif is transgressive.

(4) Sequence stratigraphy is undertaken most successfully where the structure is relatively simple and exposure is relatively continuous along strike. Ideas can be developed in a single measured section, but mapping of physical surfaces is required to test specific interpretations. Incised valleys, which are critical to the interpretation of sequence boundaries in ramp settings (iv in Fig. 1), may not be encountered in a random section. Mapping is needed also to sort out structural complications that might be missed in a measured section (Christie-Blick, 1991b). Surfaces are traced most efficiently with the help of aerial photographs (stereopairs, at a scale of between 1:40,000 and 1:5,000) and, where cliff exposures are available, by means of photographic panoramas.

(5) Thick stratigraphic sections ( $>5 \mathrm{~km}$ in the case of Neoproterozoic examples) provide the best opportunity for resolving the greatest number of sequences. In thin stratigraphic sections, unconformity surfaces tend to amalgamate producing composite breaks. Contrary to the conventional perception of unconformities, the abundance of sequence boundaries in a thick Neo- 
proterozoic succession (such as in the Flinders Ranges) should be regarded as an indicator of the rich preservation of geological events rather than of the absence of stratigraphic completeness.

\section{Examples from the Neoproterozoic of South Australia}

Ongoing studies in the Neoproterozoic and Cambrian of South Australia (Fig. 2) reveal the presence of numerous unconformity-bounded sequences in a succession that is as much as $15 \mathrm{~km}$ thick. Our current interpretation of sequences in the upper two-thirds of this succession is shown by means of a composite stratigraphic section in Fig. 3. The numbering of sequence boundaries is informal, and included only for the sake of clarity. Sequence boundaries are referred for convenience to conventional lithostratigraphic units, but the precise position of many boundaries varies at a regional scale along with both the lithic character (facies) and thicknesses of the units involved. The apparent abundance of sequence boundaries in the Wilpena Group relative to the underlying Umberatana Group is in part a function of the greater field effort undertaken in the Wilpena Group, and in part due to the great thickness of rather monotonous siltstone and glacial-marine diamictite in the Umberatana Group. Much of our detailed work has been in the interval from the upper part of the Elatina Formation to the Wonoka Formation, and it is in this interval that our sequencestratigraphic interpretations are best established. Interpretations for the interval between the Bonney Sandstone and Uratanna Formation are based largely on the work of J.G. Gehling, J.F. Mount and C. McDonald (references in the figure caption) along with our reconnaissance of critical outcrops. Interpretations of the Umberatana Group are taken in part from the geological synthesis of the Adelaide geosyncline by Preiss (1987), in part from the work of G.M. Young, N.M. Lemon and V.A. Gostin on the glacial deposits, and in part from reconnaissance by the first author. Space restrictions preclude detailed documentation of the evidence, which has and will be published elsewhere. Included here are two examples from the lower part of the Wilpena Group that serve to illustrate the methodology and uncertainties in interpretation at regional to local scale.
The rocks are not well dated (see summary in Christie-Blick et al., 1990). The best constraint is a U-Pb zircon age of $802 \pm 10 \mathrm{Ma}$ on the Rook Tuff (Fanning et al., 1986), a unit that lies stratigraphically well below the Umberatana Group. In Fig. 3, we have tentatively assumed on this basis that the thick Sturtian glacial rocks in the lower part of the Umberatana Group are younger than about $770 \mathrm{Ma}$, an age that is consistent with an $\mathrm{Rb}-\mathrm{Sr}$ date of $750 \mathrm{Ma}$ from the overlying Tapley Hill Formation (Webb and Coats, 1980) and with the timing of widespread and purportedly coextensive glaciation in western North America (Hoffman, 1991; Link et al., 1993; Powell et al., 1993). Given the large uncertainties in $\mathrm{Rb}-\mathrm{Sr}$ dating of sedimentary rocks, a somewhat younger age for the base of the Umberatana Group is possible, perhaps as young as $700 \mathrm{Ma}$. However, a recent suggestion that the Umberatana Group might be younger than $650 \mathrm{Ma}$ (Walter et al., 1995) is speculative, and requires most available dates from Australia to be disregarded, along with the proposed positioning of Australia with North America in the Proterozoic supercontinent Rodinia. The base of the Elatina Formation in the upper part of the Umberatana Group is tentatively assigned an age of $\sim 610 \mathrm{Ma}$ on the assumption that the Elatina (Marinoan glacial unit) correlates at least in part with the Varanger glacial deposits of the North Atlantic region (Conway Morris, 1989; Harland et al., 1990; Knoll and Walter, 1992). The main uncertainty in this now widely quoted age for the Varanger glaciation is that in the Avalon terrane of Newfoundland, where much of the U-Pb geochronology has been obtained, it is not clear whether the glacial rocks (Gaskiers Formation) represent the entire span or only part of the Varanger interval (Harland et al., 1990). It is therefore conceivable that the base of the Elatina Formation is either older than or younger than $610 \mathrm{Ma}$. The age of $545 \mathrm{Ma}$ for the PrecambrianCambrian boundary (Fig. 3) is taken from the recent work of Bowring et al. (1993) in Siberia.

The Umberatana and Wilpena groups are each divisible into two major cycles of sedimentation. Each cycle is characterized by overall shoaling and/or upward coarsening, and informally numbered in Fig. 3 to draw attention to the gross characteristics of the succession. Episodic rifting during deposition of the lower part of the Umberatana Group (lower part of cycle 1) is indicated by pronounced lateral variations in stratigraphic thickness and by the development of angular uncon- 


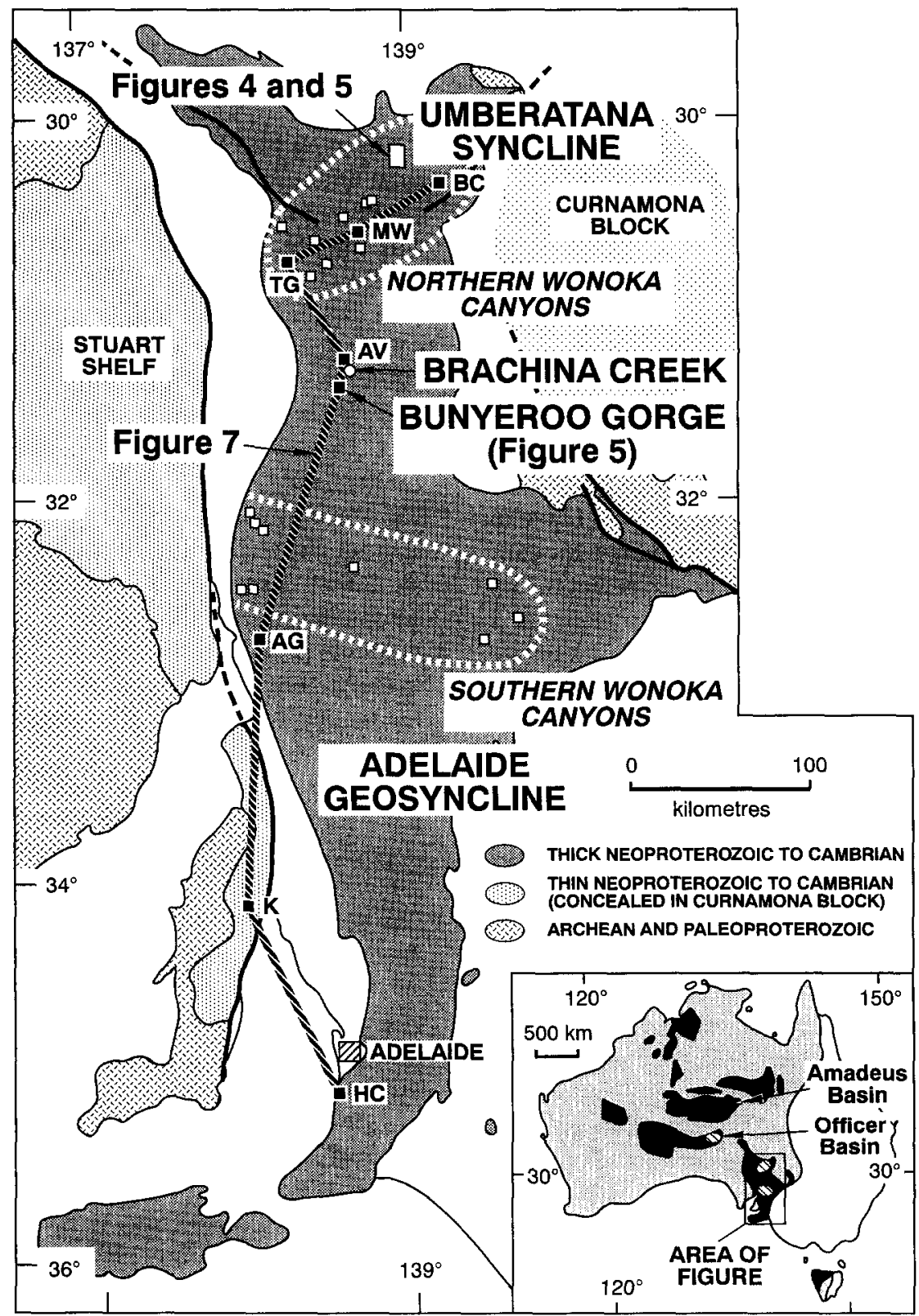

Fig. 2. Location map of the Adelaide geosyncline (from Preiss, 1987). Bold lines indicate selected prominent faults. Open squares represent outcrops with incised valleys or canyons within the Wonoka Formation (sequence boundary 9 in Figs. 3 and 5 ; from Christie-Blick et al., $1990 \mathrm{~b}$ ). These are grouped into sites in the northern Flinders Ranges and southern Flinders Ranges (broken white lines). The striped line and filled squares represent the location of a stratigraphic cross-section for the interval from the Elatina Formation to the ABC Range Quartzite (Fig. 7). Abbreviations: $H C=$ Hallett Cove; $K=$ Kulpara; $A G=$ Alligator Gorge; $A V=$ Aroona Valley; $T G=$ Trebilcock Gap; $M W=M a y n a r d s$ Well; $B C=$ Bolla Bollana Creek. The inset (modified from Preiss and Forbes, 1981) shows the distribution in Australia of Archean to Mesoproterozoic crust ( shaded) and of basins with appreciable thicknesses of Neoproterozoic sedimentary rocks (black). Cross-hatched ellipses within the inset map represent the distribution of the Wonoka canyons in the Adelaide geosyncline and of correlative features in the subsurface of the eastern Officer basin (from Sukanta et al., 1991). 


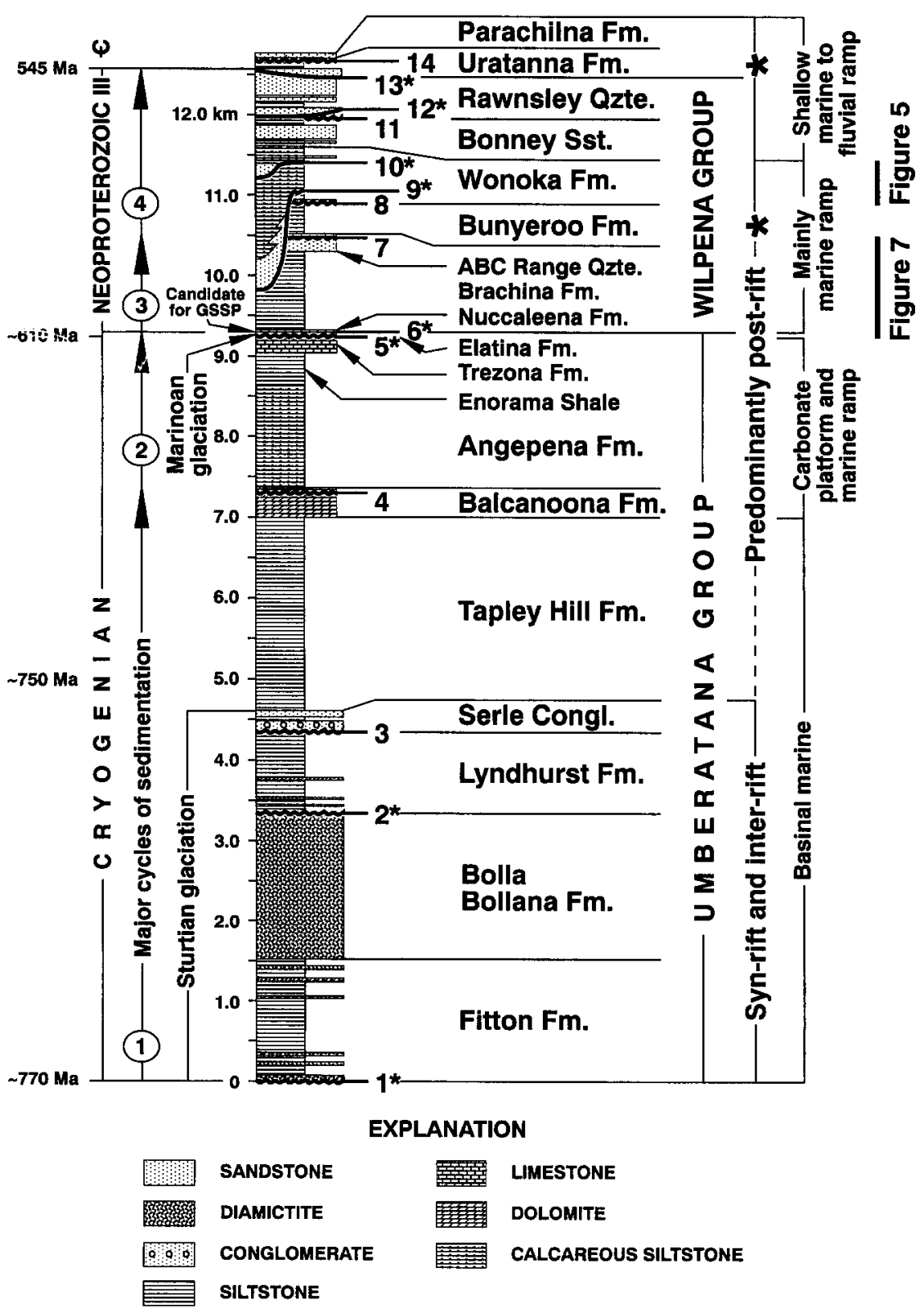

Fig. 3. Generalized stratigraphic section for the Umberatana and Wilpena groups of the central and northern Flinders Ranges, with approximate ages (see text). Numbered arrows represent the timing of four major cycles of sedimentation. The locations of the principal sequence boundaries (numbered informally) are modified from Christie-Blick et al. (1990b), and from data and interpretations presented by Gehling (1982), Jenkins et al. (1983), Preiss (1987), Young and Gostin (1988, 1989a, 1989b, 1990, 1991), DiBona et al. (1990), Lemon and Gostin (1990), McDonald (1992), Mount and McDonald (1992) and DiBona and von der Borch (1993). The most prominent boundaries are indicated by asterisks. Asterisks on the right side of the diagram indicate the timing of two inferred tectonic events, corresponding to deposition of the Bunyeroo and Uratanna formations. The suggested location for a Global Stratotype Section and Point (GSSP) for the base of a new terminal Proterozoic system (informally, Neoproterozoic III) corresponds with sequence boundary 6 at the base of the Nuccaleena Formation and correlative Seacliff Sandstone. 
formities (cf. Driscoll et al., 1995). In contrast, the succession above the Serle Conglomerate is characterized by lateral stratigraphic continuity, and appears to represent predominantly post-rift sedimentation. One difficulty with this simple picture is that if the ages indicated in Fig. 3 are assumed, it is not possible to account for the thickness of the Wilpena Group solely in terms of post-rift thermal subsidence, given a thermal time constant for lithospheric cooling of about $60 \mathrm{~m} . \mathrm{y}$. (Parsons and Sclater, 1977). This means either that the base of the Umberatana Group is substantially younger than $770 \mathrm{Ma}$ (not our preferred interpretation) or that an additional source of driving subsidence is required. Marked deepening during deposition of the Bunyeroo Formation and Uratanna Formation, corresponding with the termination of cycles 3 and 4, may indicate tectonic events, as yet poorly understood, but possibly related to the onset of crustal shortening and the development of a foreland basin to the north (W.V. Preiss, pers. commun., 1993). The termination of cycle 3 corresponds with a major reorganization and northward tilting of the Officer basin (Fig. 2; Sukanta et al., 1991), and is clearly not simply a function of eustatic change.

\subsection{Wonoka canyons}

A series of deeply incised valleys or canyons at or near the base of the Wonoka Formation (Figs. 2 and 4; sequence boundary 9 in Fig. 3) has been the focus of attention and controversy for more than a decade (Coats, 1964; Thomson, 1969; von der Borch et al., 1982, 1985, 1989; Haines, 1987; Eickhoff et al., 1988; DiBona, 1989; Christie-Blick et al., 1990b; Jenkins, 1990; Christie-Blick, 1993). These valleys were initially interpreted as submarine canyons, cut and filled in a relatively deep marine setting. The discovery of evidence for shallow-water and perhaps fluvial deposition at the lowest levels of valleys as much as $1 \mathrm{~km}$ deep casts doubt on that interpretation, but the lack of evidence for subaerial exposure in areas where valleys are absent (e.g., Bunyeroo Gorge in Figs. 2 and 5), and which, at the time of erosion, would have been many hundreds of metres above sea level has prompted efforts to explain away the supposed shallow-water indicators.

For the purpose of this paper, there is now little doubt about the scale of the erosional relief, and that correlative features are present over a broad region of the
Flinders Ranges and at what is very likely the same horizon in the eastern Officer basin (Fig. 2) some 600 $\mathrm{km}$ to the northwest (Sukanta et al., 1991). The erosional relief alone, an order of magnitude greater than typical incised valleys, argues for the presence of a sequence boundary. Although the inference of an abrupt lowering of base level depends critically on the interpretation of the canyon fill, the presence of fractured clasts of Brachina siltstone in Wonoka conglomerate and breccia (Eickhoff et al., 1988) and map evidence for marked differential compaction where wall-rocks are composed of Brachina Formation are together consistent with the existence of a significant break in sedimentation (compare with criteria discussed above). We elaborate on the facies evidence in the next section.

One of the uncertainties in the sequence-stratigraphic interpretation concerns the precise location of the sequence boundary in areas removed from the canyons. The Wonoka Formation in the central Flinders Ranges has been divided by Haines $(1987,1988,1990)$ into a series of eleven informal lithic units (Fig. 5). At several localities in the northern Flinders Ranges, the canyon-cutting unconformity appears to rise in the stratigraphy to a horizon as high as the upper part of unit 3 (Haines, 1987). Yet detailed sedimentological studies in the reference section at Bunyeroo Gorge (Figs. 2 and 5) reveal no evidence for a major discontinuity at this level, which consists everywhere of finely laminated calcareous siltstone and is amongst the deepestwater intervals of the Wonoka (Haines, 1990). In contrast, unit 5 consists predominantly of silty limestone inferred on the basis of hummocky cross-stratification and wave ripples to have accumulated in significantly shallower water, with the most marked facies change (abrupt shoaling) being localized at the base of the unit (Haines, 1987). We suggest on this basis that the sequence boundary may rise southward within the lithic stratigraphy from unit 3 , through unit 4 (only $150 \mathrm{~m}$ thick at Bunyeroo Gorge) to the base of unit 5 (Christie-Blick, 1993). This interpretation is consistent with available stratigraphic data, but admittedly difficult to test owing to the absence of appropriately continuous outcrop at the critical horizon. If large base-level changes were involved in the cutting of the canyons, it is also necessary to account for the apparent absence of evidence for subaerial exposure at the base of unit 5 at Bunyeroo Gorge. Among several possible 


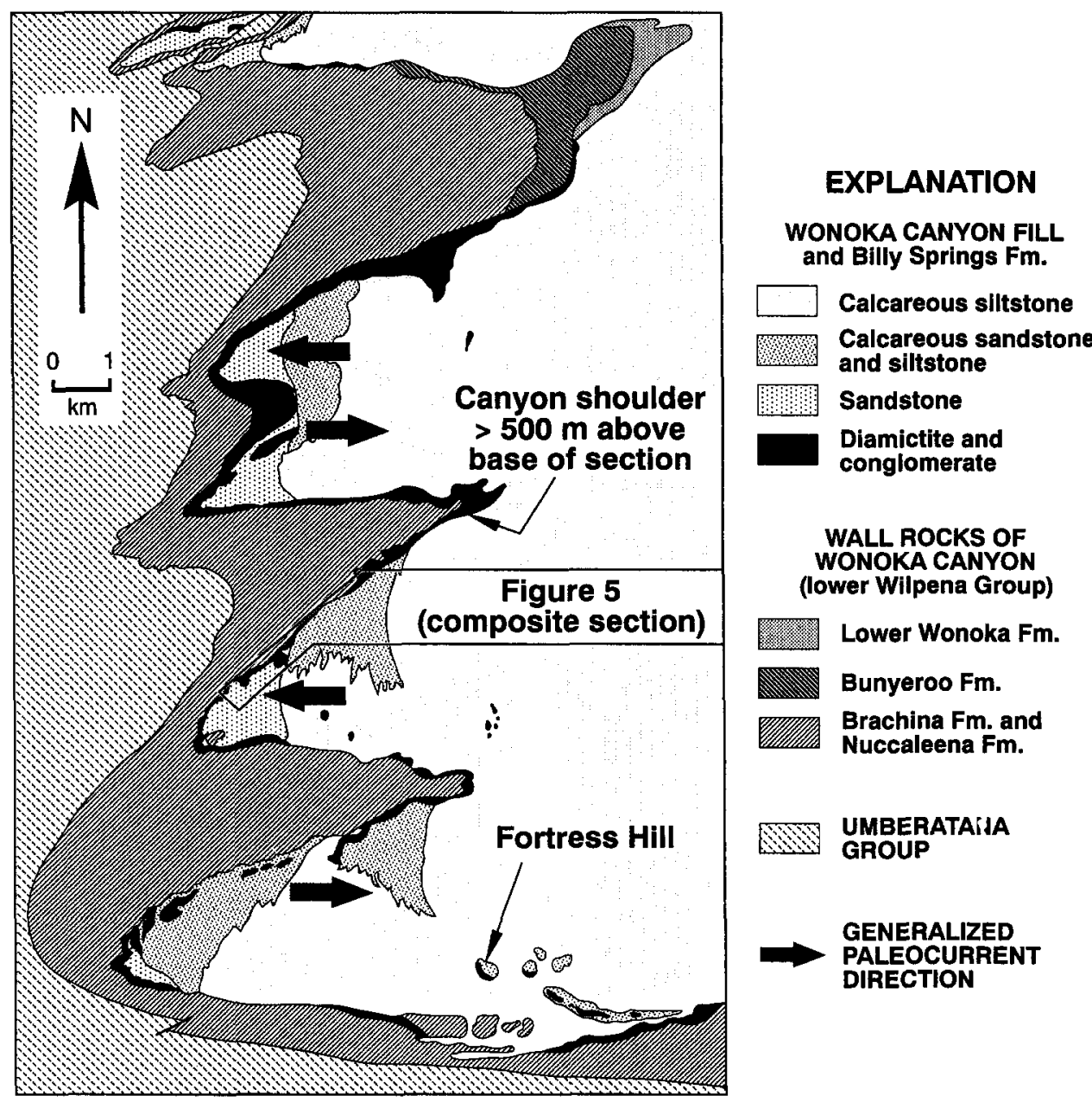

Fig. 4. Generalized geological map of the Fortress Hill canyon complex in the Wonoka Formation at Umberatana syncline in the northern Flinders Ranges (see Fig. 2 for location), modified from von der Borch et al. (1985) and Eickhoff et al. (1988). The box in the centre of the figure represents the area recently studied in detail, and the source of stratigraphic data summarized in Fig. 5.

factors are a relatively dry climate, relatively stable original mineralogy (e.g., low-magnesium calcite rather than aragonite), exposure for only a limited time and/or the removal of evidence during subsequent transgression. The preserved record of subaerial exposure in carbonate successions is commonly quite subtle (e.g., García-Mondéjar and Fernández-Mendiola, 1993; Holmes and Christie-Blick, 1993). Although the Wonoka canyons are unusual in many respects, they illustrate the general point that the character of a single physical surface may vary greatly from one place to another, and that apparent concordance even over large areas does not preclude the existence of a very significant stratigraphic discontinuity.

\subsection{High-resolution sequence stratigraphy of the Wonoka canyons}

In an attempt to resolve some of the continuing disagreements about the sedimentological significance of the Wonoka canyons, the first author has begun to reevaluate the facies in a high-resolution sequence-stratigraphic context, and initial results are summarized here as an example of high-resolution studies. The best 


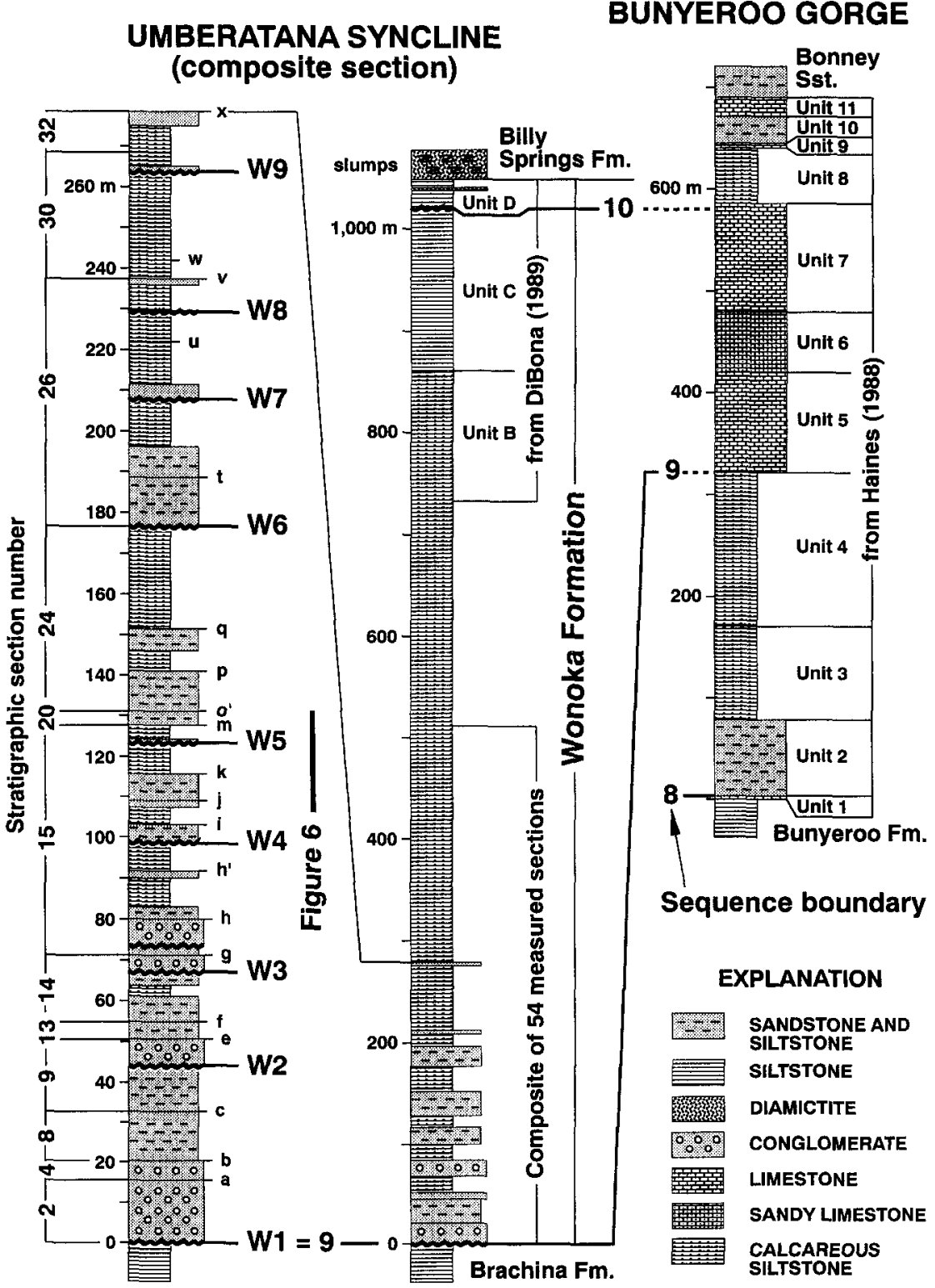

Fig. 5. Composite stratigraphic sections for the Wonoka Formation at Umberatana syncline, with additional data from DiBona (1989), and for Bunyeroo Gorge in the central Flinders Ranges (from Haines, 1988). See Figs. 2 and 4 for location. Surfaces 8 to 10 refer to regional sequence boundaries shown in Fig. 3. Details for the lower part of the Wonoka Formation at Umberatana syncline are expanded on the left, simplified from a series of 54 measured sections as indicated. Surfaces $W 1$ to $W 9$ are interpreted high-order sequence boundaries within the Wonoka canyon. Horizons $a$ to $x$ are other mapped surfaces, mainly flooding surfaces (parasequence and parasequence set boundaries).

preserved and best exposed canyon is at Umberatana syncline (Figs. 2 and 4; von der Borch et al., 1985; Eickhoff et al., 1988; Christie-Blick et al., 1990b).
There, the Wonoka Formation crops out in a series of three "incisions" into the Brachina Formation (in this area termed Ulupa Siltstone). The Bunyeroo Forma- 
tion and sub-canyon Wonoka Formation are preserved only locally above the Brachina on the shoulder of the northernmost incision (actually a double incision in the shape of a W) and locally on the southern limb of Umberatana syncline, the latter not shown in Fig. 4 (von der Borch et al., 1985; Eickhoff et al., 1988; DiBona, 1989). In places, the erosion surface cuts almost to the level of the Nuccaleena Formation, and relief in the preserved Brachina Formation alone is in excess of $500 \mathrm{~m}$. An unusual feature of the Wonoka at this locality is that the incisions appear to correspond to successive oblique sections through a single sinuous valley, which is characterized by systematic changes in paleocurrent orientation from one incision to the next (von der Borch et al., 1985; Eickhoff et al., 1988). A total of 54 closely spaced, bed-by-bed sections have been measured along the northern part of the second incision (Figs. 4 and 5), and correlated by means of mapping at a scale of 1:10,000 of physical surfaces on stereopairs of enlarged colour aerial photographs. On the basis of this work, it is now evident that the canyon fill is highly cyclic and, we argue, composed of a series of high-order sequences and parasequence sets. A cross-section documenting one of the sequence boundaries (W5) is shown in Fig. 6.

The principal components of the canyon fill are calcareous siltstone and sandstone, for the most part fineto very fine-grained, and ranging from diffusely to well-stratified. Typical sedimentary structures in these rocks are flute casts and grooves, even parallel laminae with well-developed parting lineation, and threedimensional current ripples and climbing ripples. Less common, although present throughout the lower $275 \mathrm{~m}$ of the succession in somewhat coarser-grained sandstone, is large-scale trough cross-stratification. Ripples previously interpreted by Eickhoff et al. (1988) and Christie-Blick et al. (1990b) as due to combined flow (unidirectional flow with a superimposed oscillatory component) are now regarded by the first author as for the most part current ripples. However, rare examples of symmetrical ripples, in some cases with sharp crests, and with tuning-fork bifurcations in plan view, appear to be wave ripples or wave-modified ripples, as previously reported. Subsidiary components of the canyon fill are carbonate-clast conglomerate/breccia and siltstone-clast diamictite, especially along the northern margin of each incision. The conglomerate is important to the sequence-stratigraphic interpretation because, although some is relatively disorganized, particularly at the base of the succession, much is well-stratified to cross-stratified, with few of the attributes of mass-flow deposits (Walker, 1992). The diamictite, which is typically disorganized, was derived by mass wasting of the canyon walls, and in places is interstratified with the other facies. The least abundant facies consists of thin beds of laminated silty micritic limestone. These are observed preferentially on the upper reaches of the canyons walls, but are now known to grade laterally within the canyon fill into cross-laminated calcareous siltstone (e.g., Fig. 6), and their distribution within the stratigraphy is reciprocal to the conglomerate and diamictite. Some of the limestone has laminae that are of possible microbial origin, and in places disrupted by gas- or fluid-escape structures.

As recognized initially by K.-H. Eickhoff, several aspects of the Wonoka canyons seem to require deposition in a shallow-water environment (Christie-Blick et al., 1990b). Although our perception of the evidence has evolved in detail, the overall picture has survived close scrutiny. The main arguments are as follows.

(1) Paucity of mass-flow deposits. With the exception of the diamictite and relatively disorganized conglomerate near the base of the succession, very little of the canyon fill accumulated as a result of mass-flow processes. Much of the conglomerate is stratified to cross-stratified, and although associated sandstone and siltstone has some attributes of "event layers" (for example, sole marks), few if any beds resemble classical turbidites with Bouma sequences, in spite of appropriate grain size (R.G. Walker and others, pers. commun., 1986). Rather, the event layers appear to have accumulated from turbulent streamflows under conditions of rapid but waning discharge. No dish structures or other fluid-escape features have been observed in sandstone associated with conglomerate in the Wonoka canyons, in contrast to numerous published examples of such features in mass-flow deposits elsewhere (Hein and Walker, 1982; Pickering et al., 1989; Mutti, 1992; Stow, 1992; Walker, 1992).

(2) Wave-influenced sedimentation. In spite of the reinterpretation by the first author of most previously interpreted wave-influenced structures as largely of current origin, consistent with deposition in a sinuous canyon system that would surely have been protected from significant wave activity, some sharp-crested symmetrical ripples appear to be vortex wave ripples, 


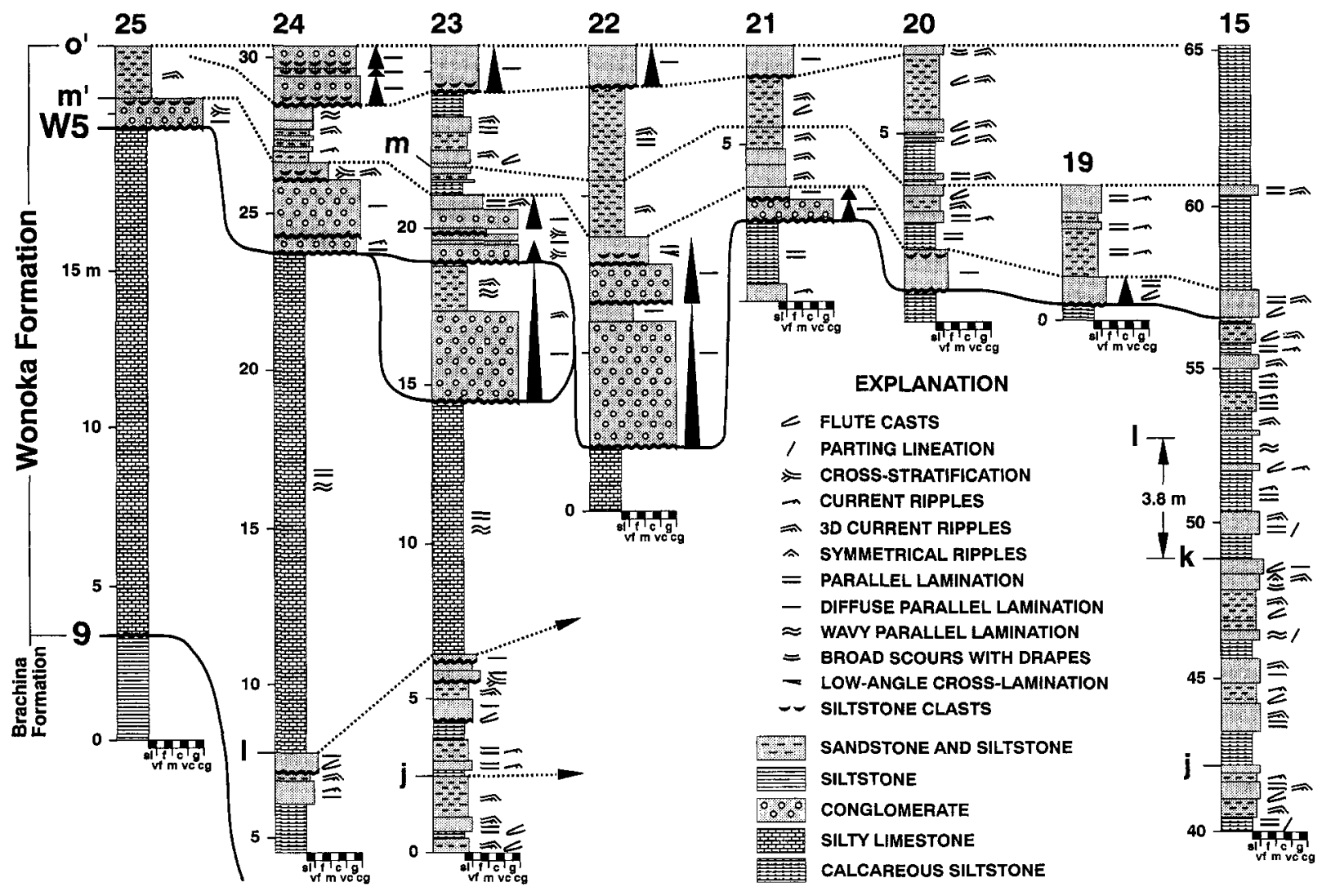

Fig. 6. Details of stratal and facies relations at the level of sequence boundary W5 in the Fortress Hill canyon complex at Umberatana syncline, from relevant parts of sections 15 and 19 to 25 (see Figs. 4 and 5 for location). The distance between sections 15 and 25 is approximately 400 $\mathrm{m}$, measured from south to north, approximately perpendicular to the orientation of paleocurrents and towards the canyon wall, with slightly more than half of this distributed between sections 15 and 19. Surface 9 is the canyon-cutting unconformity (see Fig. 3). Horizons $j, k, l, m^{\prime}$, $m$ and $o^{\prime}$ are selected mapped parasequence boundaries. Column width indicates lithology and grain size, with abbreviations from the Wentworth scale ( $s l=$ siltstone; $v f$ to $v c=$ sandstone range; $g$ and $c g=$ conglomerate range). Triangles indicate systematic grain-size changes (upward fining). Note the erosional relief and facies discontinuity at composite surface $W 5$, and the lateral facies changes away from the canyon wall from silty limestone to calcareous siltstone, from conglomerate to sandstone, and from sandstone and siltstone to calcareous siltstone. The interval between horizons $j$ and $l$ thickens southward away from the canyon wall as a result of differential compaction. The interval from $l$ to $o^{\prime}$ thickens anomalously towards the canyon wall, perhaps owing to regional northward tilting of the depositional surface.

and they strongly support the interpretation of shallowwater conditions.

(3) High-order sequences. Conglomerate is not distributed randomly through the succession, but closely associated with erosion surfaces characterized by as much as $10-15 \mathrm{~m}$ of relief (Fig. 6). These features are interpreted as valleys at high-order sequence boundaries rather than large channels on the basis of their greater scale in comparison with typical channels in the succession, and because facies discontinuities (upward coarsening) are present even where the local erosional relief is minimal and conglomeratic rocks are absent (e.g., sections 19 and 20 in Fig. 6). Although the succession tends to fine upwards at the $10-100^{+} \mathrm{m}$ scale, upward coarsening at the $10 \mathrm{~m}$ scale is observed beneath several inferred sequence boundaries (e.g., W3 in Fig. 5). In addition, at the scale of a few metres, the succession is composed of parasequences that coarsen, thicken and become increasingly channelized upwards, and which are overlain by siltstone at laterally persistent surfaces interpreted as flooding surfaces (many of the surfaces designated by letters in Figs. 5 and 6). 
Systematic upward coarsening of this sort is not the motif expected from the cutting and filling of random thalweg channels in a deep-water submarine canyon. The possibility that these features are levees can also be discounted because they do not pass laterally into channels of equivalent scale. Perhaps the most surprising new discovery is that the interpreted high-order sequences are of remarkably consistent thickness (approximately $28 \mathrm{~m}$; Fig. 5). This observation is readily explained if the sediments accumulated in shallow water, where they would be sensitive to episodic (periodic?) base-level change, but not if sedimentation took place in deep water. Even if the supply of coarsegrained sediment was modulated by some periodic mechanism, there seems to be no reason for erosion surfaces to be equally spaced in deep water. Note that some of the variability in sequence thickness apparent in Fig. 5 is due to the intersection of valleys (surfaces W3 and W8); the interval from W5 to W6 represents a double cycle.

Interpretation. The high-order valleys are interpreted by the first author to have been cut in a subaerial environment as a result of episodic lowering of depositional base level. The conglomerate is thought to represent rapid tractional sedimentation in a fluvial or fluvially dominated, shallow drowned-valley setting. Transgression was accompanied by marked fining of the sediment presumably because underflows responsible for sandstone and siltstone event layers were not sufficiently competent to transport coarse detritus more than a short distance from the river mouth. The event layers may be explained in two ways. If the valleys were drowned by saline water, the underflows could have been generated by episodic failure of a delta front. Alternatively, if the valleys were drowned by fresh water (or at least water of low salinity), then the underflows could represent direct input of river water during times of flood, with hyperpycnal conditions being maintained by the excess density of the sediment-laden flows with respect to the ambient water. The beds of laminated limestone are here interpreted as subaqueous hardgrounds deposited during intervals of maximum flooding. Limestone is preserved preferentially along the canyon walls not because it is a subaerial tufa (Eickhoff et al., 1988; Christie-Blick et al., 1990b) but because only there was it not subject to dilution by terrigenous mud and reworking by currents.
Overall, the canyon fill is interpreted to deepen upwards-a large-scale transgressive systems tract composed of backstepping high-order sequences (cf. fig. 2 of Jenkins et al., 1992). Individual high-order sequences tend to be asymmetrical, with thick transgressive intervals composed of backstepping parasequences, and thinner regressive intervals associated with forestepping parasequences (high-order highstands). The degree of asymmetry tends to increase upwards from one sequence to the next, although a distinct if relatively fine-grained highstand unit is present immediately below sequence boundary W9. Above that level, sequence boundaries can no longer be objectively identified, and the succession is divided into backstepping parasequence sets (not shown in Fig. 5). The development of prominent high-order sequences within a large-scale transgressive systems tract is unusual, and may indicate base-level changes that were of relatively large amplitude and/or of high frequency. The possibility that the high-order cyclicity is related to astronomical forcing of the Earth's climate (Milankovitch band) is currently being evaluated quantitatively. Although we recognize that no consensus has yet been reached on the origin of the Wonoka canyons, this example illustrates the utility of high-resolution sequence stratigraphy in sedimentological interpretation.

\subsection{Nuccaleena Formation/Seacliff Sandstone to $A B C$ Range Quartzite}

A second example discussed here concerns the sequence stratigraphy of the interval from the Nuccaleena Formation/Seacliff Sandstone to the ABC Range Quartzite (Fig. 3). It is an important interval in the Flinders Ranges because it encompasses one candidate horizon for a GSSP, approximately at the level of the Nuccaleena. It also includes a large-scale transgressive-regressive cycle that is in places more than 1000 $\mathrm{m}$ thick (cycle 3 in Fig. 3), as well as a good deal of higher-order cyclicity in the upper part of the Brachina Formation and in the ABC Range Quartzite. Hence, sequence boundaries might be expected to be well developed. Ironically, in spite of considerable effort on the part of all three authors, and in contrast to the upper part of the Wilpena Group (cycle 4 in Fig. 3), incised valleys have proven somewhat elusive. 


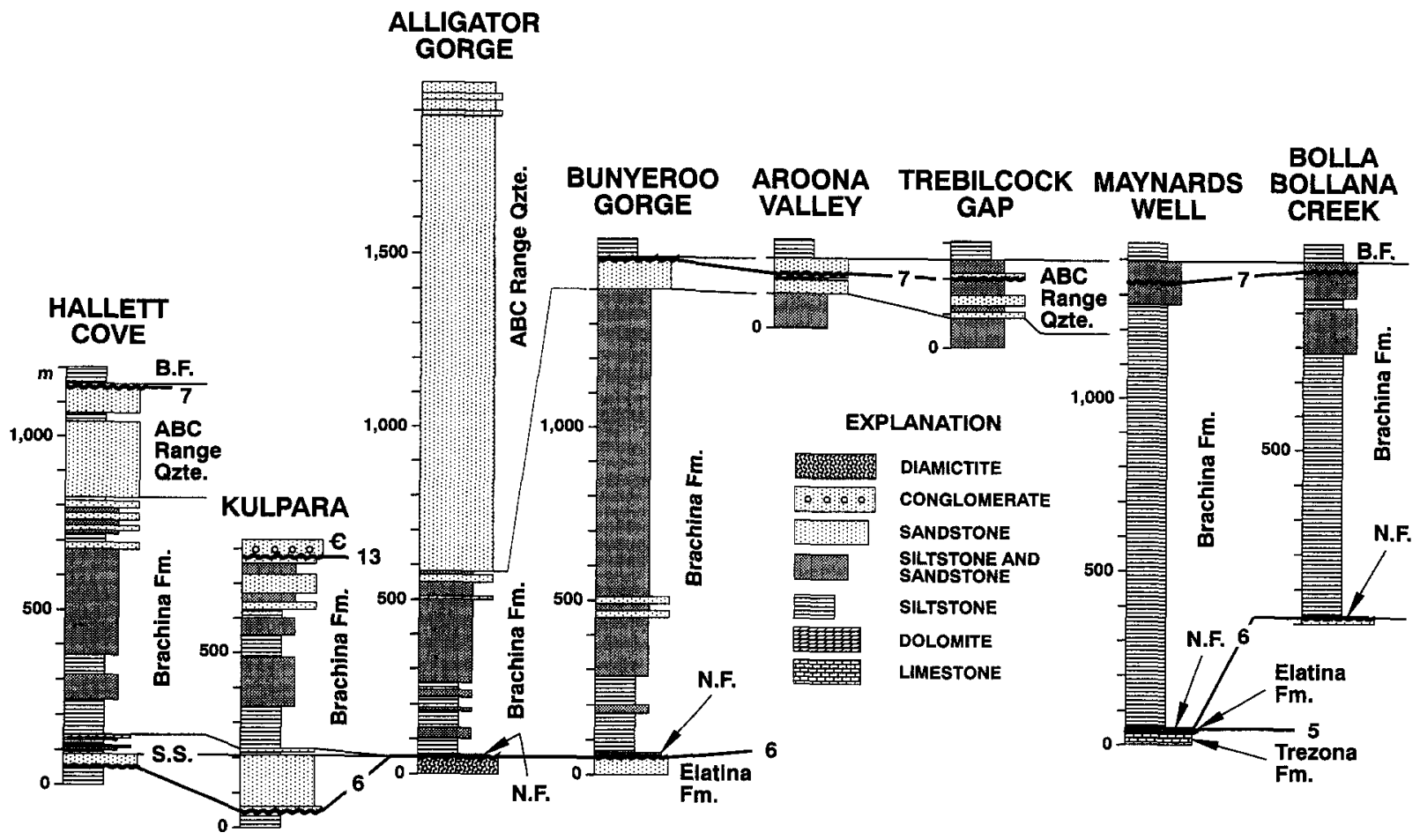

Fig. 7. Regional stratigraphic cross-section for the interval between the top of the Elatina Formation and the Bunyeroo Formation (B.F.). See Fig. 2 for location. Data for Hallett Cove, Kulpara, Alligator Gorge and Bunyeroo Gorge are from the work of Dyson. The remaining sections are generalized from detailed logs measured by Christie-Blick. The distance between Hallett Cove and Bolla Bollana Creek is approximately $600 \mathrm{~km}$ along the line of the cross-section, and $520 \mathrm{~km}$ in a straight line. Datums are (left) the first major flooding surface within the Seacliff Sandstone (S.S.) or the base of the Nuccaleena Formation (N.F.), and (right) the top of the ABC Range Quartzite or Brachina Formation. Surfaces $5,6,7$ and 13 are regional sequence boundaries shown in Fig. 3.

The main elements of the succession are as follows. The Nuccaleena Formation is a regionally persistent marker no more than a few metres thick, composed of distinctive pink to buff-coloured laminated dolomite that unconformably to disconformably overlies Marinoan glacial strata of the Umberatana Group and grades upwards into siltstone of the Brachina Formation (Dalgarno and Johnson, 1964; Plummer, 1978a; Preiss, 1987; Christie-Blick et al., 1990b; Dyson, 1992). Stromatolites, possible tepee structures and intraclast breccias are present locally within the Nuccaleena, but in most sections shallow-water indicators are absent, and the Nuccaleena is interpreted to have accumulated for the most part in a subtidal/sub-wave-base environment. The Brachina Formation consists of a thick succession (more than $1000 \mathrm{~m}$ ) of siltstone and minor sandstone that in turn passes upwards into several tens to hundreds of metres of cyclic quartzite, sandstone and siltstone of the ABC Range Quartzite. With the exception of the lower part of the Brachina, shallow-water indicators such as gutter casts, subaqueous shrinkage cracks, wave ripples, interference ripples, hummocky cross-stratification and trough cross-stratification associated with multimodal paleocurrents, are common, and they indicate gradual shoaling upwards through the succession (Dalgarno and Johnson, 1964; Plummer, 1978b,c, 1990; Preiss, 1987; Christie-Blick et al., 1990b; Dyson, 1992). In places, the Nuccaleena Formation appears to pass laterally into cyclic sandstone and siltstone containing hummocky cross-stratification, facies that are generally assigned to the Seacliff Sandstone (Forbes, 1982; Preiss, 1987; Dyson, 1992; Dyson and von der Borch, 1994). A regional stratigraphic cross-section for these units is shown in Fig. 7, 
extending from Hallett Cove in the south to Bolla Bollana Creek in the northern Flinders Ranges (Fig. 2).

The overall interpretation of this succession in terms of a large-scale transgressive-regressive cycle is relatively straightforward. However, debate continues about the precise placement of sequence boundaries. One of the main difficulties is that the base of the Nuccaleena (N.F. in Fig. 7) is a regional flooding surface that in many places is associated with abrupt deepening rather than shoaling of sedimentary facies (von der Borch et al., 1988). The interpretation of this contact as a sequence boundary amalgamated with a flooding surface (von der Borch et al., 1988; Christie-Blick et al., 1990b) is based on: (1) the very remarkable contrast in facies with respect to underlying clastic rocks of the Umberatana Group; and (2) evidence for erosional truncation of the uppermost Umberatana Group along the southern limb of Umberatana syncline (Fig. 2; Coats, 1973). Recent work in the Seacliff Sandstone (S.S. in Fig. 7) corroborates the presence of a sequence boundary at the Nuccaleena level (Dyson, 1992; Dyson and von der Borch, 1994). At Hallett Cove (HC in Fig. 2), the Seacliff overlies the Reynella Siltstone Member of the Elatina Formation at an erosional contact (Fig. 7). Pisolitic pebble conglomerate is present at the same horizon at Kulpara ( $\mathrm{K}$ in Fig. 2), where the base of the Seacliff also appears to cut out as much as several hundred metres of the Umberatana Group. Dyson and von der Borch (1994) tentatively interpret the contact as the edge of an incised valley. The evidence is equivocal, however, because it is not possible in available outcrop to demonstrate onlap of the Seacliff Sandstone. An alternative interpretation is that the inferred erosional truncation is related to tilting of the underlying strata prior to deposition of the Seacliff Sandstone, as appears to be the case beneath the Nuccaleena Formation at Umberatana syncline.

Identification of a sequence boundary in the $A B C$ Range Quartzite is still more problematical. Erosion surfaces described at the top of this unit at several localities (e.g., Plummer, 1978b, 1978c) have in nearly all cases proven to be incised valleys associated with younger sequence boundaries (such as the Wonoka canyons) or faults (Christie-Blick, 1991b). Facies discontinuities characterized by subtle evidence for upward shoaling are present within the ABC Range Quartzite at Aroona Valley and Trebilcock Gap (Fig.
7; AV and TG in Fig. 2), in both cases associated with a change in the stacking pattern of parasequences from forestepping to backstepping. Elsewhere (for example, Bunyeroo Gorge), the inferred sequence boundary appears to be amalgamated with a flooding surface at or near the top of the ABC (Christie-Blick et al., 1990b). It is therefore possible that at Aroona Valley and Trebilcock Gap the sequence boundary is lower in the lithostratigraphy owing to the existence of a broad incised valley (or valleys), but the mapping needed to verify this interpretation has not yet been completed. Given the higher-order cyclicity in the ABC Range Quartzite, it is important to avoid miscorrelation of physical surfaces between sections. The sections at Maynards Well and Bolla Bollana Creek (MW and BC in Fig. 2) represent still more basinward settings. The sequence boundary is interpreted to lie within the coarse upper part of the laterally equivalent Brachina Formation at horizons corresponding to an abrupt increase in the sand/shale ratio, but is conceivably located still higher in the Brachina (cf. Fig. 1C). More proximal facies in the ABC Range Quartzite cannot be examined, for example at Kulpara, Alligator Gorge (AG in Fig. 2) and on the Stuart shelf, because they have been removed by subsequent erosion.

\section{Towards a Neoproterozoic global framework}

In Neoproterozoic rocks, sequence stratigraphy is useful primarily as a framework for synthesizing stratigraphic observations at the scale of a single sedimentary basin. However, if at least some sequence boundaries are of global extent, as we have suggested ought to be the case (Christie-Blick et al., 1990b), it is useful to assess briefly the extent to which individual boundaries persist laterally from the Adelaide geosyncline to the Amadeus basin of central Australia (Fig. 2). A prime objective of the International Stratigraphic Commission Working Group on the Terminal Proterozoic System is to select a section and horizon suitable for definition of a GSSP for the base of a new system. Here we consider selection criteria in a sequence-stratigraphic context.

\subsection{Comparison with the Amadeus basin}

The sequence stratigraphy of the Adelaide geosyncline is compared with that of the Amadeus basin in 


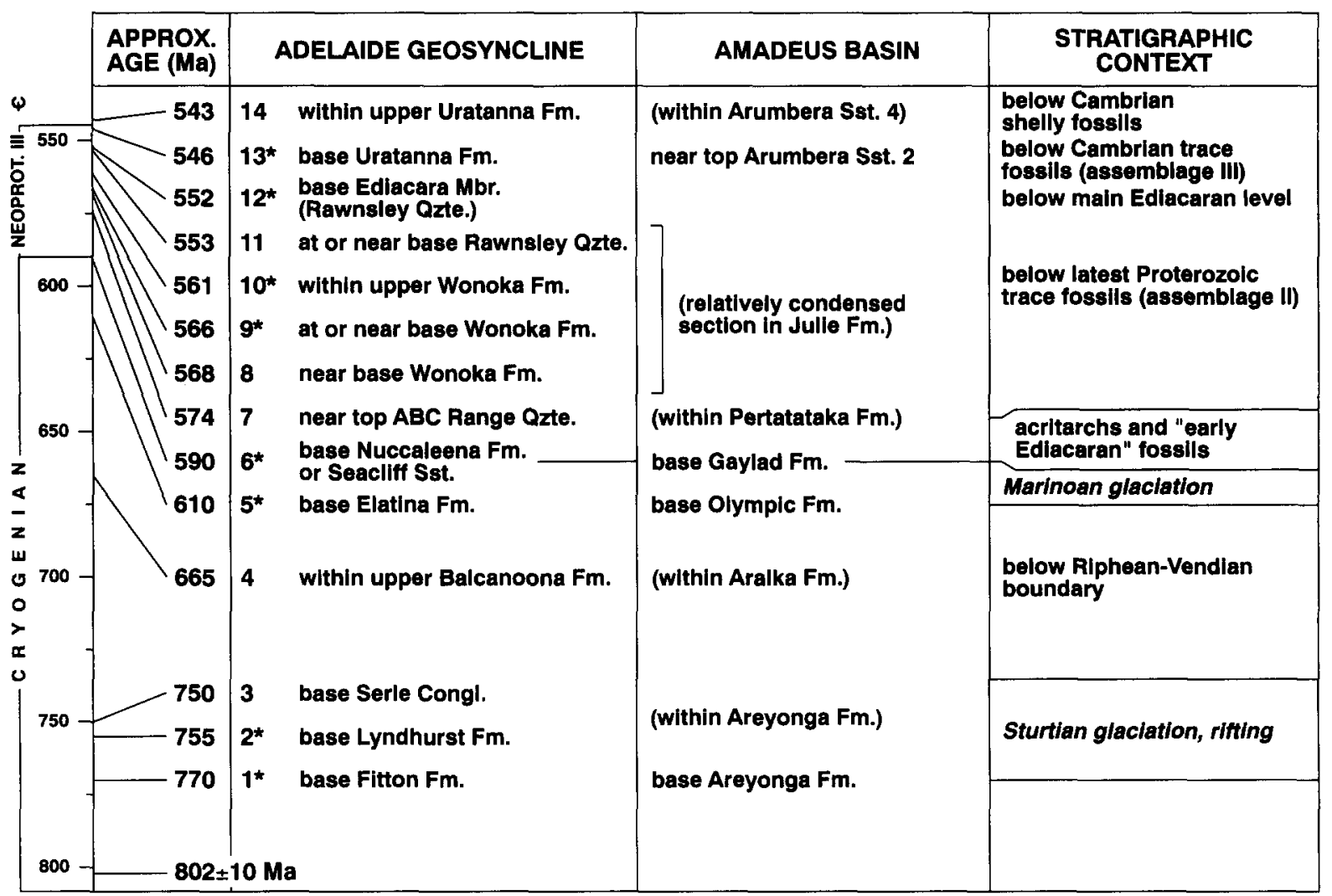

Fig. 8. Sequence-stratigraphic comparison of the Adelaide geosyncline and Amadeus basin, using data and interpretations from Fig. 3 and, for the Amadeus basin, modified from Lindsay $(1987,1993)$ and Lindsay and Korsch (1989, 1991), with input from M.J. Kennedy. Ages indicated for sequence boundaries are approximate only, and were obtained by linear interpolation between tie points in Fig. 3 . The most prominent boundaries are indicated by asterisks. Annotations in parentheses in the column for the Amadeus basin indicate the approximate location of horizons in the stratigraphy where no specific correlative sequence boundary has been identified. Several potential sequence boundaries are present in the interval between the Pertatataka Formation and Arumbera Sandstone, which is relatively condensed at the level of the Julie Formation, but no firm correlations with several prominent sequence boundaries in the Adelaide geosyncline are yet possible. The context of the sequence-stratigraphic interpretation with respect to the timing of glaciation and rifting and published information on acritarchs, Ediacaran body fossils, trace fossils and shelly fossils is indicated on the right (from Webb and Coats, 1980; Dyson, 1985; Fanning et al., 1986; Preiss, 1987; Walter et al., 1989; Zang and Walter, 1989, 1992; Lindsay and Korsch, 1991; Knoll and Walter, 1992; Mount and McDonald, 1992; Bowring et al., 1993; Jenkins et al., 1993).

Fig. 8. The scheme shown is very tentative owing to uncertainties in the interpretation of both basins, and it is best regarded as a hypothesis in need of a good deal of further evaluation. We have done little detailed work in the Amadeus basin, and the interpretation for that area is modified from the publications of J.F. Lindsay and colleagues on the basis of observations by the first author mainly during and immediately following an international excursion arranged under the auspices of IGCP Project 320 in May, 1993 (Jenkins et al., 1993).
We acknowledge critical input from many field trip participants, especially M.J. Kennedy for insights about the section between the Aralka and Julie formations (Kennedy, 1993, 1994). Sequence boundaries in the Adelaide geosyncline have been assigned approximate ages on the basis of the very tentative calibration summarized in Fig. 3 and the simplifying assumption of constant rates of sediment accumulation between tie points. The Marinoan glacial deposits are assigned a span of 20 m.y., and for the purpose of Fig. 8, 750 Ma 
is taken as the age of the base of the Serle Conglomerate. In spite of the obvious uncertainties in this exercise, attempts to assign numerical ages to Neoproterozoic events in other sections have made use of similar assumptions (Knoll and Walter, 1992), and in view of its relative completeness, the Adelaide geosyncline is arguably one of the better places to make such estimates. As more $\mathrm{U}-\mathrm{Pb}$ ages become available from Neoproterozoic rocks, the scheme is testable and subject to revision.

The most secure correlations are at the level of the Sturtian and Marinoan glacial deposits (sequence boundaries 1, 5 and 6 in Fig. 8) and in the vicinity of the Precambrian-Cambrian boundary (sequence boundary 13). Boundaries 1 and $5(\sim 770 \mathrm{Ma}$ and $\sim 610 \mathrm{Ma})$ correspond with the onset of glaciation. Boundary 6 ( $\sim 590 \mathrm{Ma})$ at the base of the Nuccaleena Formation/Seacliff Sandstone is of uncertain origin. It may be associated with glacial-isostatic rebound, and in that case it is arguably correlative at least within the region affected by the Marinoan ice sheet. The stratigraphy of the Marinoan glacial rocks and immediately overlying strata in the Amadeus basin is complicated by lateral variations in facies and inconsistent usage of a plethora of lithostratigraphic names (Preiss et al., 1978; Lindsay, 1989; Field, 1991; Freeman et al., 1991; Jenkins et al., 1993). Recent work by M.J. Kennedy (pers. commun., 1993) confirms the presence of a prominent sequence boundary at or near the base of the post-glacial (?) Gaylad Sandstone (depending on how that unit is mapped), and an attractive hypothesis is that this surface corresponds with boundary 6 in the Adelaide geosyncline.

In the Adelaide geosyncline, the Precambrian-Cambrian boundary is located on the basis of trace fossils in the lower part of the middle member of the Uratanna Formation, no more than a few tens of metres above sequence boundary 13 (at the base of the Uratanna; $\sim 546 \mathrm{Ma}$ ), a surface characterized by incised valleys with many tens of metres of erosional relief (Daily, 1973; McDonald, 1992; Mount and McDonald, 1992). In the Amadeus basin, the Precambrian-Cambrian boundary has been interpreted from trace and body fossils to be within unit 3 of the Arumbera Formation (Lindsay, 1987; Walter et al., 1989, 1995; Lindsay and Korsch, 1989, 1991). According to Lindsay (1987) and Lindsay and Korsch (1991), the nearest sequence boundary of late Neoproterozoic age is at the top of unit 2 of the Arumbera. We suggest that it may be slightly lower. At the reference outcrop section at Ross River (Lindsay, 1987), the top of unit 2 is a marine flooding surface, and objective evidence for the presence of a sequence boundary at that horizon is lacking. In addition, seismic reflection data appear to have been misinterpreted. The presence of well-developed offlap (fig. 14 of Lindsay, 1987) indicates that the boundary is located one seismic cycle lower than the horizon interpreted by Lindsay (that is, within unit 2, a possibility raised also by Mount and McDonald, 1992). In the course of recent reconnaissance with M.J. Kennedy at Gaylad syncline, the first author documented a 23m-deep incised valley within unit 2 as predicted. We infer that this sequence boundary may correlate with the one at the base of the Uratanna Formation in the Adelaide geosyncline.

Sequence boundaries 2 and 3 at the base of the Lyndhurst Formation and base of the Serle Conglomerate in the Adelaide geosyncline formed during a time of crustal extension and fault-block tilting (Fig. 3), and may not be traceable beyond the local basin of sedimentation. The section in the Amadeus basin between the glaciogenic Areyonga and Olympic formations is relatively condensed, owing to a generally lower rate of subsidence. In spite of gross lithic similarities, no distinctive markers can be traced from the Adelaide geosyncline, and there is no way yet to evaluate potential correlations. Similarly, in the section above the Olympic Formation, although sequence boundaries are suspected at several horizons, correlation is to a large extent an exercise in lithic comparison aided by imprecise information about the distribution of trace and body fossil assemblages, acritarchs and isotopic excursions (Preiss et al., 1978; Walter et al., 1995). Incised valleys comparable in scale to those of the upper Wilpena Group in the Adelaide geosyncline have not been observed in the Amadeus basin, and we infer on this basis that the "Centralian Superbasin" of Walter et al. (1995) may already have been partially disrupted, isolating the Amadeus basin from the Adelaide geosyncline, prior to the cutting of the Wonoka canyons (sequence boundary $9 ; \sim 566 \mathrm{Ma}$ ).

In spite of these difficulties, several of the sequence boundaries within the Wilpena Group of the Adelaide geosyncline are very prominent, and depending to some extent on why this is the case, we cannot exclude the possibility that some are of eustatic origin. Evidence 
for sequence boundaries at comparable stratigraphic horizons ought to be sought on other continents. The most prominent surfaces, all characterized at least locally by erosional relief of many tens of metres, are sequence boundaries 9 (Wonoka canyons; 566 Ma), 10 (upper Wonoka Formation; $\sim 561 \mathrm{Ma}$ ) and 12 (base of the Ediacara Member of the Rawnsley Quartzite; $\sim 552 \mathrm{Ma}$ ). Boundaries 9 and 10 are both located above the level of "early Ediacaran" body fossils (Dyson, 1985) and large complex acritarchs (Zang and Walter, 1989, 1992; Knoll and Walter, 1992), but below the level of latest Proterozoic trace fossils (assemblage II of Walter et al., 1989) and the main Ediacaran interval (Jenkins et al., 1983). Boundary 12 is below the main Ediacaran interval, but within the interval containing assemblage II trace fossils.

\subsection{Selection criteria for a Global Stratotype Section and Point}

An emerging consensus is that placement of a Global Stratotype Section and Point for the base of a new terminal Proterozoic system should reflect some combination of criteria, possibly including the timing of climate change (Varanger ice age), variations in $\mathrm{C}$ and/or $\mathrm{Sr}$ isotopes, acritarch appearances or extinctions, and the appearances of Ediacaran metazoans and trace fossils (Knoll and Walter, 1992). As a matter of philosophy the GSSP might be selected so as to separate, at least approximately, spans of geological time that are identifiably different. Alternatively, the GSSP could be chosen more or less arbitrarily but taking into account previous usage of such terms as Vendian, Sinian and Ediacaran (the view advanced by W.B. Harland). In either case, as a purely practical matter, the GSSP ought to be selected within an interval that can be correlated globally and as precisely as possible by means of a number of independent techniques.

In addition to these considerations, we propose that the GSSP be located also with respect to physical stratigraphy. In the Phanerozoic, virtually all important chronostratigraphic boundaries, including the recently ratified Precambrian-Cambrian boundary (Landing, 1994), correspond with intervals of sediment starvation (iss in Fig. 1) because these are also the intervals for which evolutionary changes are best defined and in which basinal sedimentation tends to be most continuous and unifacial (Loutit et al., 1988). Unconformi- ties are avoided for the purpose of biochronology because they usually correspond with resolvable hiatuses and with changes in sedimentary facies that tend to influence the distribution of fossils. However, given the lack of precision in biostratigraphy and isotope geochemistry in Neoproterozoic rocks, and in a marked departure from Phanerozoic practice, we recommend placement of the GSSP at a sequence boundary. The main justification for this is that in contrast to all of the other potential stratigraphic constraints in Neoproterozoic successions, sequence boundaries are surfaces.

Amongst criteria that might be applied in the selection of a suitable sequence boundary are the following: (1) great lateral extent within a single sedimentary basin or continental block; (2) a close association with other geological "events" useful in correlation, including proximity to horizons datable by means of $\mathrm{U}-\mathrm{Pb}$ geochronology; (3) an associated hiatus that is relatively short and/or that can be minimized by tracing the sequence boundary laterally to a correlative conformity; and (4) the likelihood that correlative sequence boundaries may be identifiable on other continents. In the absence of adequate geochronology, the hiatus associated with a sequence boundary in a specific section may be difficult to assess quantitatively, but qualitative arguments can be made on the basis of physical stratigraphic relations (regional onlap and offlap) if the sequence boundary is traceable over a large area. Problems that might arise hypothetically from the existence of even a small hiatus at the chosen GSSP can be handled by specifying the age of the GSSP as the age of the correlative conformity of the chosen sequence boundary. Although it may never be possible to establish conclusively that sequence boundaries on different continents are correlative, boundaries that are individually present over large areas, temporally associated with continental glaciation and coeval within the limits of available dating techniques are good candidates. In practice, any attempt at global correlation would necessarily involve all available stratigraphic criteria, and this is not precluded by the selection of a GSSP at a sequence boundary using the above criteria.

On the basis of these considerations, the most suitable horizon for a GSSP would be at a sequence boundary at the level of the Varanger glacial strata. In the case of the Adelaide geosyncline, two candidates are available: sequence boundary 5 at the base of the Elatina Formation, and sequence boundary 6 at the base 
of the Nuccaleena Formation/Seacliff Sandstone (Figs. 3 and 8). Both appear to be traceable over a distance of more than $1000 \mathrm{~km}$. Both can be traced laterally within the Adelaide geosyncline into relatively thick basinal successions (Preiss, 1987; Lemon and Gostin, 1990), where the associated hiatus is likely to be small. Our preferred horizon is boundary 6 , for three reasons. First, in proposing a GSSP we are swayed by the notion of attempting to separate an interval of widespread glaciation from one that was for the most part non-glacial. Second, boundary 6 directly underlies the Nuccaleena Formation, a so-called cap dolomite associated with a prominent and distinctive negative shift in $\delta^{13} \mathrm{C}$ (Williams, 1979; Calver, 1993; Frick and Gostin, 1995). Third, assuming an origin related to regional deglaciation, we suspect that this sequence boundary may represent a smaller hiatus in sedimentation than sequence boundary 5 . If sequence boundary 6 developed primarily as a result of glacial-isostatic rebound rather than eustatic change, for example, then correlative boundaries exist on other continents only if deglaciation was more or less synchronous. On the basis of emerging carbon-isotopic data (Kaufman et al., 1993; Kaufman et al., 1995) we regard such synchroneity as at least plausible at achievable age resolution, and we recommend a systematic study of the sequence-stratigraphic context of all purported Varanger cap carbonates.

A prime area for defining a GSSP in the Adelaide geosyncline is in the vicinity of Bunyeroo Gorge and Brachina Creek (Figs. 2 and 7). The area is easily accessible, well mapped, and structurally simple. Although outcrop quality is variable, there are plenty of sections in this region at which exposure is continuous from the Elatina Formation into the Brachina Formation. In view of the confidence with which this horizon can be traced laterally over many tens of kilometres, the precise geographic location of the GSSP is not an important issue. Indeed, it would make little practical difference if the GSSP was defined at the same horizon in the Amadeus basin (at or near the base of Gaylad Sandstone/Pertatataka Formation). Our only proviso is that the GSSP should be specified with respect to a regionally mappable surface, whether or not this is also a lithostratigraphic contact at the section selected.

\section{Conclusions}

In this paper we have attempted to address some of the practical issues inherent in the application of sequence stratigraphy to Neoproterozoic successions, and the implications of such analysis for the interpretation of Neoproterozoic earth history. The emergence of sequence stratigraphy does not imply that existing techniques or data ought to be discarded. Nor is it a panacea for stratigraphic problems; interpretive uncertainties exist at many levels. However, by focussing on the three-dimensional configuration of stratigraphic discontinuities within sedimentary successions, sequence stratigraphy can provide a unifying framework in which observations of intrinsic rock characteristics such as lithology, facies, fossil content, chemistry, magnetic remanence and age can be compared and correlated. Departing from Phanerozoic practice, we recommend placement of a terminal Proterozoic GSSP at a sequence boundary, specifically at the level of the Varanger glaciation. A suitable surface in Australia is the sequence boundary at the base of the immediately post-glacial Nuccaleena Formation/Seacliff Sandstone in the Adelaide geosyncline, and its likely correlative at or near the base of the Gaylad Sandstone in the Amadeus basin.

\section{Acknowledgements}

This paper is an outgrowth of several years of joint research in Australia, supported in part by the Donors of the Petroleum Research Fund, administered by the American Chemical Society (PRF 16042-G2 and PRF 19989-AC2), by National Science Foundation grant EAR 92-06084, by the Arthur D. Storke Memorial Fund of the Department of Geological Sciences, Columbia University, and by Esso Australia Ltd., the Flinders University Research Budget and the Australian Research Grants Scheme. We thank J.F. Mount and P.M. Myrow for their thorough reviews of the manuscript, the editors for their patience, and colleagues too numerous to name individually for stimulating discussions about many aspects of the work. This paper is a contribution to Project 320 of the International Geological Correlation Programme (Neoproterozoic Events and Resources), and Lamont-Doherty Earth Observatory Contribution No. 5270. 


\section{References}

Baum, G.R. and Vail, P.R., 1988. Sequence stratigraphic concepts applied to Paleogene outcrops, Gulf and Atlantic basins. In: C.K. Wilgus, B.S. Hastings, C.G.St.C. Kendall, H.W. Posamentier, C.A. Ross and J.C. Van Wagoner (Editors), Sea-Level Changes: An Integrated Approach. Soc. Econ. Paleontol. Mineral. Spec. Publ., 42: 309-327.

Berg, O.R. and Woolverton, D.G. (Editors), 1985. Seismic Stratigraphy, Il. An Integrated Approach to Hydrocarbon Exploration. Am. Assoc. Pet. Geol. Mem. 39, 276 pp.

Bowring, S.A. and Grotzinger, J.P., 1992. Implications of new chronostratigraphy for tectonic evolution of Wopmay orogen, northwest Canadian shield. Am. J. Sci., 292: 1-20.

Bowring, S.A., Grotzinger, J.P., Isachsen, C.E., Knoll, A.H., Pelechaty, S.M. and Kolosov, P., 1993. Calibrating rates of Early Cambrian evolution. Science, 261: 1293-1298.

Calver, C.R., 1993. Appendix A: chemostratigraphy of Ediacarian successions in the Adelaide Geosyncline, Amadeus Basin and Officer Basin. In: R.J.F. Jenkins, J.F. Lindsay and M.R. Walter (Editors), Field Guide to the Adelaide Geosyncline and Amadeus Basin, Australia. Aust. Geol. Surv. Organ. Rec., 1993/35: $82-84$.

Christie-Blick, N., 1982. Upper Proterozoic and Lower Cambrian rocks of the Sheeprock Mountains, Utah: regional correlation and significance. Geol. Soc. Am. Bull., 93: 735-750.

Christie-Blick, N., 1991a. Onlap, offlap, and the origin of unconformity-bounded depositional sequences. Mar. Geol., 97: 35-56.

Christie-Blick, N., 1991b. Layer-parallel faulting in the Flinders Ranges, Australia: a re-interpretation of Patsy Springs Canyon (Neoproterozoic). Geol. Soc. Am. Abstr. Progr., 23: A60.

Christie-Blick, N., 1993. Wonoka canyons, Umberatana syncline. In: R.J.F. Jenkins, J.F. Lindsay and M.R. Walter (Editors), Field Guide to the Adelaide Geosyncline and Amadeus Basin, Australia. Aust. Geol. Surv. Organ. Rec., 1993/35: 29-31.

Christie-Blick, N. and Driscoll, N.W., 1995. Sequence stratigraphy. Ann. Rev. Earth Planet. Sci., 23: 451-478.

Christie-Blick, N. and Levy, M., 1985. A new approach to time correlation in Proterozoic rocks: sequence boundaries in the Brigham Group, Utah. Geol. Soc. Am. Abstr. Progr., 17: 546.

Christie-Blick, N. and Levy, M., 1989. Concepts of sequence stratigraphy, with examples from strata of late Proterozoic and Cambrian age in the western United States. In: N. Christie-Blick and M. Levy (Editors), Late Proterozoic and Cambrian Tectonics, Sedimentation, and Record of Metazoan Radiation in the Western United States. 28th Int. Geol. Congr. Field Trip Guidebook T331, Am. Geophys. Union, pp. 23-37.

Christie-Blick, N. and von der Borch, C.C., 1985. Sequence boundaries in Proterozoic successions: a comparison of the Brigham Group (Utah) and Wilpena Group (South Australia), with implications for sea-level change and global correlation. Geol. Soc. Am. Abstr. Progr., 17: 546.

Christie-Blick, N., Grotzinger, J.P. and von der Borch, C.C., 1988. Sequence stratigraphy in Proterozoic successions. Geology, 16: 100-104

Christie-Blick, N., Mountain, G.S. and Miller, K.G., 1990a. Seismic stratigraphic record of sea-level change. In: Sea-Level Change.
Studies in Geophysics, National Academy Press, Washington, D.C., pp. 116-140.

Christie-Blick, N., von der Borch, C.C. and DiBona, P.A., $1990 \mathrm{~b}$. Working hypotheses for the origin of the Wonoka canyons ( Neoproterozoic), South Australia. Am. J. Sci., 290-A: 295-332.

Coats, R.P., 1964. Large scale Precambrian slump structures, Flinders Ranges. Q. Geol. Notes, Geol. Surv. South Aust., 11: 1-2.

Coats, R.P., 1973. Copley, South Australia. Geol. Surv. South Australia, geological map, sheet SH 54-9, 1:250,000 scale.

Conway Morris, S., 1989. South-eastern Newfoundland and adjacent areas (Avalon Zone). In: J.W. Cowie and M.D. Brasier (Editors), The Precambrian-Cambrian Boundary. Clarendon Press, Oxford, pp. 7-39.

Cross, T.A. and Lessenger, M.A., 1988. Seismic stratigraphy. Ann. Rev. Earth Planet. Sci., 16: 319-354.

Daily, B., 1973. Discovery and significance of basal Cambrian Uratanna Formation, Mt Scott Range, Flinders Ranges, South Australia. Search, 4: 202-205.

Dalgarno, C.R. and Johnson, J.E., 1964. Wilpena Group (new name). Q. Geol. Notes, Geol. Surv. South Aust., 9: 12-16.

Deynoux, M., Proust, J.N. and Simon, B., 1991. Late Proterozoic glacially controlled shelf sequences in western Mali (West Africa). J. Afr. Earth Sci., 12: 181-198.

DiBona, P.A., 1989. Geologic History and Sequence Stratigraphy of the Late Proterozoic Wonoka Formation, Northern Flinders Ranges, South Australia. Flinders Univ., Adelaide, S.A., Ph.D. dissert., $207 \mathrm{pp}$.

DiBona, P.A. and von der Borch, C.C., 1993. Sedimentary geology and evolution of an outcropping shelf-margin delta, Late Proterozoic Wonoka Formation, South Australia. Am. Assoc. Pet. Geol. Bull., 77: 963-979.

DiBona, P.A., von der Borch, C.C. and Christie-Blick, N., 1990. Sequence stratigraphy and evolution of a basin-slope succession: the Late Proterozoic Wonoka Formation, Flinders Ranges, South Australia. Aust. J. Earth Sci., 37: 135-145.

Driscoll, N.W., Hogg, J.R., Christie-Blick, N. and Karner, G.D., 1995. Extensional tectonics in the Jeanne d'Are Basin. offshore Newfoundland: implications for the timing of break-up between Grand Banks and lberia. In: R.A. Scrutton, M.S. Stoker, G.B. Shimmield and A.W. Tudhope (Editors), The Tectonics, Sedimentation and Palaeoceanography of the North Atlantic Region. Geol. Soc. London Spec. Publ., 90: 1-28.

Dunbar, C.O. and Rodgers, J., 1957. Principles of Stratigraphy. John Wiley and Sons, New York, $356 \mathrm{pp}$.

Dyson, I.A., 1985. Frond-like fossils from the base of the late Precambrian Wilpena Group, South Australia. Nature, 318: 283285.

Dyson, I.A., 1992. Stratigraphic nomenclature and sequence stratigraphy of the lower Wilpena Group, Adelaide Geosyncline: the Sandison Subgroup. Q. Geol. Notes, Geol. Surv. South Aust., 122: 2-13.

Dyson, I.A. and von der Borch, C.C., 1994. Sequence stratigraphy of an incised valley fill: the Neoproterozoic Seacliff Sandstone, Adelaide geosyncline, South Australia. In: R.W. Dalrymple, R. Boyd and B.A. Zaitlin (Editors), Incised-Valley Systems: Origin and Sedimentary Sequences. SEPM (Soc. for Sediment. Geol.) Spec. Publ., 51: 209-222. 
Eickhoff, K.-H., von der Borch, C.C. and Grady, A.E., 1988. Proterozoic canyons of the Flinders Ranges (South Australia): submarine canyons or drowned river valleys? Sediment. Geol., 58: 217-235.

Fanning, C.M., Ludwig, K.R., Forbes, B.G. and Preiss, W.V., 1986. Single and multiple grain $\mathrm{U}-\mathrm{Pb}$ zircon analyses for the early Adelaidean Rook Tuff, Willouran Ranges, South Australia. Geol. Soc. Aust., Abstr., 15: 71-72.

Field, B.D., 1991. Paralic and periglacial facies and contemporaneous deformation of the Late Proterozoic Olympic Formation, Pioneer Sandstone and Gaylad Sandstone, Amadeus Basin, central Australia. In: R.J. Korsch and J.M. Kennard (Editors), Geological and Geophysical Studies in the Amadeus Basin, Central Australia. Bur. Miner. Resour. Geol. Geophys., Bull., 236: 127136.

Forbes, B.G., 1982. Minor changes in stratigraphic nomenclature, Adelaidean System, late Proterozoic. Q. Geol. Notes, Geol. Surv. South Aust., 82: 2-3.

Freeman, M.J., Oaks, R.Q.. Jr. and Shaw, R.D., 1991. Stratigraphy of the Late Proterozoic Gaylad Sandstone, northeastern Amadeus Basin, and recognition of an underlying regional unconformity. In: R.J. Korsch and J.M. Kennard (Editors), Geological and Geophysical Studies in the Amadeus Basin, Central Australia. Bur. Miner. Resour. Geol. Geophys., Bull., 236: 137-169.

Frick, L.R. and Gostin, V.A., 1995. Oxygen and carbon isotopes indicate changing marine environments following the Marinoan (Neoproterozoic) ice age, Flinders Ranges, South Australia. Aust. J. Earth Sci., in press.

García-Mondéjar, J. and Fernández-Mendiola, P.A., 1993. Sequence stratigraphy and systems tracts of a mixed carbonate and siliciclastic platform-basin setting: the Albian of Lunada and Soba, northern Spain. Am. Assoc. Pet. Geol. Bull., 77: 245-275.

Gehling, J.G., 1982. The Sedimentology and Stratigraphy of the Late Precambrian Pound Subgroup, Central Flinders Ranges, South Australia. Univ. Adelaide, Adelaide, S.A., M.Sc. thesis, 112 pp.

Gravestock, D.I. and Hibburt, J.E., 1991. Sequence stratigraphy of the eastern Officer and Arrowie basins: a framework for Cambrian oil search. APEA J., 31: 177-190.

Greenlee, S.M., Devlin, W.J., Miller, K.G., Mountain, G.S. and Flemings, P.B., 1992. Integrated sequence stratigraphy of Neogene deposits, New Jersey continental shelf and slope: comparison with the Exxon model. Geol. Soc. Am. Bull., 104: 14031411.

Grotzinger, J.P., Adams, R.D., McCormick, D.S. and Myrow, P., 1989. Sequence stratigraphy, correlations between Wopmay orogen and Kilohigok basin, and further investigations of the Bear Creek Group (Goulburn Supergroup), District of Mackenzie, N.W.T. Geol. Surv. Can., Pap., 89-1C: 107-119.

Haines, P.W., 1987. Carbonate Shelf and Basin Sedimentation, Late Proterozoic Wonoka Formation, South Australia. Univ. Adelaide, Adelaide, S.A., Ph.D. thesis, 152 pp.

Haines, P.W., 1988. Storm-dominated mixed carbonate/siliciclastic shelf sequence displaying cycles of hummocky cross-stratification, late Proterozoic Wonoka Formation, South Australia. Sediment. Geol., 58: 237-254.

Haines, P.W., 1990. A late Proterozoic storm-dominated carbonate shelf sequence: the Wonoka Formation in the central and south- ern Flinders Ranges, South Australia. In: J.B. Jago and P.S. Moore (Editors), The Evolution of a Late Precambrian-Early Palaeozoic Rift Complex: The Adelaide Geosyncline. Geol. Soc. Aust., Spec. Publ., 16: 177-198.

Haq, B.U., 1991. Sequence stratigraphy, sea-level change, and significance for the deep sea. In: D.I.M. Mcdonald (Editor), Sedimentation, Tectonics and Eustasy. Sea-Level Changes at Active Margins. Int. Assoc. Sedimentol. Spec. Publ., 12: 3-39.

Haq, B.U., Hardenbol, J. and Vail, P.R., 1987. Chronology of fluctuating sea levels since the Triassic. Science, 235: 1156-1167.

Harland, W.B., Armstrong, R.L., Cox, A.V., Craig, L.E., Smith, A.G. and Smith, D.G., 1990. A Geologic Time Scale 1989. Cambridge Univ. Press, Cambridge, 263 pp.

Hein, F.J. and Walker, R.G., 1982. The Cambro-Ordovician Cap Enragé Formation, Québec, Canada: conglomeratic deposits of a braided submarine channel with terraces. Sedimentology, 29: 309-329.

Hoffman, P.F., 1991. Did the breakout of Laurentia turn Gondwanaland inside-out? Science, 252: 1409-1412.

Holmes, A.E. and Christie-Blick, N., 1993. Origin of sedimentary cycles in mixed carbonate-siliciclastic systems: an example from the Canning basin, Western Australia. In: R.G. Loucks and J.F. Sarg (Editors), Carbonate Sequence Stratigraphy. Recent Developments and Applications. Am. Assoc. Pet. Geol. Mem., 57: 181-212.

Jenkins, R.J.F., 1990. The Adelaide Fold Belt: tectonic reappraisal. In: J.B. Jago and P.S. Moore (Editors), The Evolution of a Late Precambrian-Early Palaeozoic Rift Complex: The Adelaide Geosyncline. Geol. Soc. Aust., Spec. Publ., 16: 396-420.

Jenkins, R.J.F., Ford, C.H. and Gehling, J.G., 1983. The Ediacara Member of the Rawnsley Quartzite: the context of the Ediacara assemblage (late Precambrian, Flinders Ranges), J. Geol. Soc. Aust., 30: 101-119.

Jenkins, R.J.F., McKirdy, D.M., Foster, C.B., O'Leary, T. and Pell, S.D., 1992. The record and stratigraphic implications of organicwalled microfossils from the Ediacaran (terminal Proterozoic) of South Australia. Geol. Mag., 129: 401-410.

Jenkins, R.J.F., Lindsay, J.F. and Walter, M.R. (Editors), 1993. Field Guide to the Adelaide Geosyncline and Amadeus Basin, Australia. Aust. Geol. Surv. Organ. Rec. 1993/35, 133 pp.

Kaufman, A.J. and Knoll, A.H., 1995. Neoproterozoic variations in the C-isotopic composition of seawater: stratigraphic and biogeochemical implications. In: A.H. Knoll and M. Walter (Editors), Neoproterozoic Stratigraphy and Earth History. Precambrian Res., 73: 27-49 (this volume).

Kaufman, A.J., Jacobsen, S.B. and Knoll, A.H., 1993. The Vendian record of $\mathrm{Sr}$ and $\mathrm{C}$ isotopic variations in seawater: implications for tectonics and paleoclimate. Earth Planet. Sci. Lett., 120:409430.

Kennedy, M.J., 1993. The Undoolya sequence: Late Proterozoic salt influenced deposition, Amadeus basin, central Australia. Aust. J. Earth Sci., 40: 217-228.

Kennedy, M.J., 1994. The Influence of Diapirism and Deglaciation on the Development of the Neoproterozoic Stratigraphy of the Amadeus Basin, Central Australia. Univ. Adelaide, Adelaide, S.A., Ph.D. dissert., 186 pp. 
Knoll, A.H. and Walter, M.R., 1992. Latest Proterozoic stratigraphy and earth history. Nature, 356: 673-678.

Landing, E., 1994. Precambrian-Cambrian boundary global stratotype ratified and a new perspective of Cambrian time. Geology, 22: 179-182.

Lemon, N.M. and Gostin, V.A., 1990. Glacigenic sediments of the late Proterozoic Elatina Formation and equivalents, Adelaide Geosyncline, South Australia. In: J.B. Jago and P.S. Moore (Editors), The Evolution of a Late Precambrian-Early Palaeozoic Rift Complex: The Adelaide Geosyncline. Geol. Soc. Aust., Spec. Publ., 16: 149-163.

Levy, M.E., 1991. Late Proterozoic and Early Cambrian Sedimentation, Sequence Stratigraphy, and Tectonic Evolution of the Eastern Great Basin. Columbia Univ., New York, Ph.D. dissert., $380 \mathrm{pp}$.

Levy, M. and Christie-Blick, N., 1991. Late Proterozoic paleogeography of the eastern Great Basin. In: J.D. Cooper and C.H. Stevens (Editors), Paleozoic Paleogeography of the Western United States, II. Pac, Sect., Soc. Econ. Paleontol. Mineral., 67(1):371386.

Levy, M., Christie-Blick, N. and Link, P.K., 1994. Neoproterozoic incised valleys of the eastern Great Basin, Utah and Idaho: Fluvial response to changes in depositional base level. In: R.W. Dalrymple, R. Boyd and B.A. Zaitlin (Editors), Incised-Valley Systems: Origin and Sedimentary Sequences. SEPM (Soc. for Sediment. Geol.) Spec. Publ., 51: 369-382.

Lindsay, J.F., 1987. Sequence stratigraphy and depositional controls in Late Proterozoic-Early Cambrian sediments of Amadeus basin, central Australia. Am. Assoc. Pet. Geol. Bull., 71: 13871403.

Lindsay, J.F., 1989. Depositional controls on glacial facies associations in a basinal setting, Late Proterozoic, Amadeus basin, central Australia. Palaeogeogr., Palaeoclimatol., Palaeoecol., 73: $205-232$.

Lindsay, J.F., 1993. Sequence recognition in intracratonic settings. In: R.J.F. Jenkins, J.F. Lindsay and M.R. Walter (Editors), Field Guide to the Adelaide Geosyncline and Amadeus Basin, Australia. Aust. Geol. Surv. Organ. Rec., 1993/35: 45-46.

Lindsay, J.F. and Korsch, R.J., 1989. Interplay of tectonics and sealevel changes in basin evolution: an example from the intracratonic Amadeus basin, central Australia. Basin Res., 2: 3-25

Lindsay, J.F. and Korsch, R.J., 1991. The evolution of the Amadeus Basin, central Australia. In: R.J. Korsch and J.M. Kennard (Editors), Geological and Geophysical Studies in the Amadeus Basin, Central Australia. Bur. Miner. Resour. Geol. Geophys., Bull., 236: 7-32.

Link, P.K., Jansen, S.T., Halimdihardja, P., Lande, A. and Zahn, P., 1987. Stratigraphy of the Brigham Group (Late ProterozoicCambrian ), Bannock, Portneuf, and Bear River Ranges, southeastern Idaho. In: W.R. Miller (Editor), The Thrust Belt Revisited. Wyo. Geol. Assoc., Guideb., Annu. Field Conf., 38: 133148.

Link, P.K.. Christie-Blick, N., Devlin, W.J., Elston, D.P., Horodyski, R.J., Levy, M., Miller, J.M.G., Pearson, R.C., Prave, A., Stewart, J.H., Winston, D., Wright, L.A. and Wrucke, C.T., 1993. Middle and Late Proterozoic stratified rocks of the western U.S. Cordillera, Colorado Plateau, and Basin and Range province. In: J.C.
Reed, Jr., M.E. Bickford, R.S. Houston, P.K. Link, D.W. Rankin, P.K. Sims and W.R. Van Schmus (Editors), Precambrian: Conterminous U.S. The Geology of North America, Vol. C-2. Geological Society of America, Boulder, Colo., pp. 463-595.

Loutit, T.S., Hardenbol, J., Vail, P.R. and Baum, G.R., 1988. Condensed sections: the key to age determination and correlation of continental margin sequences. In: C.K. Wilgus, B.S. Hastings, C.G.St.C. Kendall, H.W. Posamentier, C.A. Ross and J.C. Van Wagoner (Editors), Sea-Level Changes: An Integrated Approach. Soc. Econ. Paleontol. Mineral. Spec. Publ., 42: I83213.

McDonald, C., 1992. Origin and Sequence Stratigraphic Significance of the Uratanna Channels, Basal Cambrian Uratanna Formation. Northern Flinders Ranges, South Australia. Univ. California. Davis, M.Sc. thesis, $90 \mathrm{pp}$.

Mitchum, R.M., Jr., 1977. Seismic stratigraphy and global changes of sea level, part 11: Glossary of terms used in seismic stratigraphy. In: C.E. Payton (Editor), Seismic Stratigraphy-Applications to Hydrocarbon Exploration. Am. Assoc. Pet. Geol. Mem., 26: 205-212.

Mitchum, R.M., Jr. and Van Wagoner, J.C., 1991. High-frequency sequences and their stacking patterns: sequence-stratigraphic evidence of high-frequency eustatic cycles. Sediment. Geol., 70: 131-160.

Mount, J.F., 1989. Re-evaluation of unconformities separating the "Ediacaran" and Cambrian systems, South Australia. Palaios, 4: $366-373$

Mount, J.F. and McDonald, C., 1992. Influence of changes in climate, sea level, and depositional systems on the fossil record of the Neoproterozoic-Early Cambrian metazoan radiation, Australia. Geology, 20: 1031-1034.

Mutti, E.. 1992. Turbidite Sandstones. Agip, Istituto di Geologia Università di Parma, 275 pp.

Myrow, P.M., 1995. Neoproterozoic rocks of the Newfoundland Avalon zone. In: A.H. Knoll and M. Walter (Editors), Neoproterozoic Stratigraphy and Earth History. Precambrian Res., 73: 123-136 (this volume).

Myrow, P.M. and Hiscott, R.N., 1993. Depositional history and sequence stratigraphy of the Precambrian-Cambrian boundary stratotype section, Chapel Island Formation, southeast Newfoundland. Palaeogeogr., Palaeoclimatol., Palaeoecol., 104: 1335 .

Parsons, B. and Sclater, J.G., 1977. An analysis of the variation of ocean floor bathymetry and heat flow with age. J. Geophys. Res.. 82: 803-827.

Pelechaty, S.M. and Grotzinger, J.P., 1993. Correlation of Vendian carbonate rocks between the Olenek uplift and the Kharaulahk Mountains, northern Siberia. Geol. Soc. Am. Abstr. Progr., 25: A337.

Pickering, K.T., Hiscott, R.N. and Hein, F.J., 1989. Deep-Marine Environments. Clastic Sedimentation and Tectonics. Unwin Hyman, London, 416 pp.

Plummer, P.S., 1978a. Note on the palaeoenvironmental significance of the Nuccaleena Formation (upper Precambrian), central Flinders Ranges, South Australia. J. Geol. Soc. Aust., 25: 395-402.

Plummer, P.S., 1978b. Stratigraphy of the lower Wilpena Group (late Precambrian), Flinders Ranges, South Australia. Trans. R. Soc South Aust., 102: 25-38. 
Plummer, P.S., 1978c. The Upper Brachina Subgroup: a Late Precambrian Intertidal Deltaic and Sandflat Sequence in the Flinders Ranges, South Australia. Univ. Adelaide, Adelaide, S.A., Ph.D. dissert., $170 \mathrm{pp}$.

Plummer, P.S., 1990. Late Precambrian wave- to tide-dominated delta evolution in the west-central Adelaide Geosyncline, South Australia. In: J.B. Jago and P.S. Moore (Editors), The Evolution of a Late Precambrian-Early Palaeozoic Rift Complex: The Adelaide Geosyncline. Geol. Soc. Aust., Spec. Publ., 16: 164-176.

Posamentier, H.W. and James, D.P., 1993. An overview of sequencestratigraphic concepts: uses and abuses. In: H.W. Posamentier, C.P. Summerhayes, B.U. Haq and G.P. Allen (Editors), Sequence Stratigraphy and Facies Associations. Int. Assoc. Sedimentol. Spec. Publ., 18: 3-18.

Posamentier, H.W. and Vail, P.R., 1988. Eustatic controls on clastic deposition II-Sequences and systems tract models. In: C.K. Wilgus, B.S. Hastings, C.G.St.C. Kendall, H.W. Posamentier, C.A. Ross and J.C. Van Wagoner (Editors), Sea-Level Changes: An Integrated Approach. Soc. Econ. Paleontol. Mineral. Spec. Publ., 42: 125-154.

Posamentier, H.W., Jervey, M.T. and Vail, P.R., 1988. Eustatic controls on clastic deposition I-Conceptual framework. In: C.K. Wilgus, B.S. Hastings, C.G.St.C. Kendall, H.W. Posamentier, C.A. Ross and J.C. Van Wagoner (Editors), Sea-Level Changes: An Integrated Approach. Soc. Econ. Paleontol. Mineral. Spec. Publ., 42: 109-124.

Posamentier, H.W., Allen, G.P., James, D.P. and Tesson, M., 1992. Forced regressions in a sequence stratigraphic framework: concepts, examples, and exploration significance. Am. Assoc. Pet. Geol. Bull., 76: 1687-1709.

Powell, C.McA., Li, Z.X., McElhinny, M.W., Meert, J.G. and Park, J.K., 1993. Paleomagnetic constraints on timing of the Neoproterozoic breakup of Rodinia and the Cambrian formation of Gondwana. Geology, 21: 889-892.

Preiss, W.V. (Compiler), 1987. The Adelaide Geosyncline. Late Proterozoic stratigraphy, sedimentation, palaeontology and tectonics. Geol. Surv. South Aust. Bull. 53, 438 pp.

Preiss, W.V. and Forbes, B.G., 1981. Stratigraphy, correlation and sedimentary history of Adelaidean (late Proterozoic) basins in Australia. Precambrian Res., 15: 255-304.

Preiss, W.V., Walter, M.R., Coates, R.P. and Wells, A.T., 1978. Lithological correlations of Adelaidean glaciogenic rocks in parts of the Amadeus, Ngalia, and Georgina basins. BMR J. Aust. Geol. Geophys., 3: 45-53.

Qiao Xiufu, Yao Peiyi and Wang Chengshu, 1991. Sequence stratigraphy and tectonic environment of the Chartai Group, Inner Mongolia. Acta Geol. Sin., 4: 217-235.

Reynolds, D.J., Steckler, M.S. and Coakley, B.J., 1991. The role of the sediment load in sequence stratigraphy: the influence of flexural isostasy and compaction. J. Geophys. Res., 96: 6931-6949.

Ross, G.M., 1991. Tectonic setting of the Windermere Supergroup revisited. Geology, 19: 1125-1128.

Sarg, J.F., 1988. Carbonate sequence stratigraphy. In: C.K. Wilgus, B.S. Hastings, C.G.St.C. Kendall, H.W. Posamentier, C.A. Ross and J.C. Van Wagoner (Editors), Sea-Level Changes: An Integrated Approach. Soc. Econ. Paleontol. Mineral. Spec. Publ., 42: $155-181$.
Saylor, B.Z., Grotzinger, J.P. and Germs, G.J.B., 1995. Sequence stratigraphy and sedimentology of the Neoproterozoic Kuibis and Schwarzrand Subgroups ( Nama Group), southwestern Namibia. In: A.H. Knoll and M. Walter (Editors), Neoproterozoic Stratigraphy and Earth History. Precambrian Res., 73: 153-171 (this volume).

Shanker, R. and Mathur, V.K., 1992. Precambrian-Cambrian sequence in Krol belt and additional Ediacaran fossils. Geophytology, 22: 27-39.

Siedlecka, A. and Roberts, D., 1992. The bedrock geology of Varanger Peninsula, Finnmark, north Norway: an excursion guide. Norg. Geol. Unders. Spec. Publ. 5, 45 pp.

Sloss, L.L., 1950. Paleozoic stratigraphy in the Montana area. Am. Assoc. Pet. Geol. Bull., 34: 423-451.

Sloss, L.L., 1963. Sequences in the cratonic interior of North America. Geol. Soc. Am. Bull., 74: 93-114.

Sloss, L.L., 1988. Forty years of sequence stratigraphy. Geol. Soc. Am. Bull., 100: 1661-1665.

Sloss, L.L., Krumbein, W.C. and Dapples, E.C., 1949. Integrated facies analysis. In: C.R. Longwell (Chairman), Sedimentary Facies in Geologic History. Geol. Soc. Am. Mem., 39: 91-124.

Stow, D.A.V. (Editor), 1992. Deep-Water Turbidite Systems. Repr. Ser. Vol. 3, International Association of Sedimentologists, Blackwell, Oxford, $473 \mathrm{pp}$.

Sukanta, U., Thomas, B., von der Borch, C.C. and Gatehouse, C.G., 1991. Sequence stratigraphic studies and canyon formation, South Australia. Petr. Expl. Soc. Aust. J., 19: 68-73.

Thomson, B.P., 1969. Precambrian basement cover, the Adelaide System. In: L.W. Parkin (Editor), Handbook of South Australian Geology. Geological Survey of South Australia, Adelaide, S.A., pp. 49-83.

Vail, P.R., 1987. Seismic stratigraphy interpretation using sequence stratigraphy, Part I. Seismic stratigraphy interpretation procedure. In: A.W. Bally (Editor), Atlas of Seismic Stratigraphy. Am. Assoc. Pet. Geol. Stud. Geol., 27( 1): 1-10.

Vail, P.R., 1992. The evolution of seismic stratigraphy and the global sea-level curve. In: R.H. Dott, Jr. (Editor), Eustasy: The Historical Ups and Downs of a Major Geological Concept. Geol. Soc. Am. Mem., 180: 83-91.

Vail, P.R., Mitchum, R.M., Jr., Todd, R.G., Widmier, J.M., Thompson, S., III, Sangree, J.B., Bubb, J.N. and Hatlelid, W.G., 1977 Seismic stratigraphy and global changes of sea level. In: C.E. Payton (Editor), Seismic Stratigraphy-Applications to Hydrocarbon Exploration. Am. Assoc. Pet. Geol. Mem., 26: 49-212.

Vail, P.R., Hardenbol, J. and Todd, R.G., 1984. Jurassic unconformities, chronostratigraphy, and sea-level changes from seismic stratigraphy and biostratigraphy. In: J.S. Schlee (Editor), Interregional Unconformities and Hydrocarbon Accumulation. Am. Assoc. Pet. Geol. Mem., 36: 129-144

Vail, P.R., Audemard, F., Bowman, S.A., Eisner, P.N. and PerezCruz, C., 1991. The stratigraphic signatures of tectonics, eustasy and sedimentology_an overview. In: G. Einsele, W. Ricken and A. Seilacher (Editors), Cycles and Events in Stratigraphy. Springer-Verlag, Berlin, pp. 617-659.

Van Wagoner, J.C., Posamentier, H.W., Mitchum, R.M., Vail, P.R., Sarg, J.F., Loutit, T.S. and Hardenbol, J., 1988. An overview of the fundamentals of sequence stratigraphy and key definitions. 
In: C.K. Wilgus, B.S. Hastings, C.G.St.C. Kendall, H.W. Posamentier, C.A. Ross and J.C. Van Wagoner (Editors), Sea-Level Changes: An Integrated Approach. Soc. Econ. Paleontol. Mineral. Spec. Publ., 42: 39-45.

Van Wagoner, J.C., Mitchum, R.M., Campion, K.M. and Rahmanian, V.D., 1990. Siliciclastic sequence stratigraphy in well logs, cores, and outcrops: concepts for high-resolution correlation of time and facies. Am. Assoc. Pet. Geol. Methods Expl. Ser. 7, 55 pp.

Von der Borch, C.C., Smit, R. and Grady, A.E., 1982. Late Proterozoic submarine canyons of Adelaide Geosyncline, South Australia. Am. Assoc. Pet. Geol. Bull., 66: 332-347.

Von der Borch, C.C., Grady, A.E., Aldam, R., Miller, D., Neumann, R., Rovira, A. and Eickhoff, K., 1985. A large-scale meandering submarine canyon: outcrop example from the late Proterozoic Adelaide Geosyncline, South Australia. Sedimentology, 32: 507-518.

Von der Borch, C.C., Christie-Blick, N. and Grady, A.E., 1986. Concepts of seismic stratigraphic analysis applied to late Proterozoic Wilpena Group, Adelaide Geosyncline, South Australia. 8th Aust. Geol. Conv. Abstr. 15, p. 197.

Von der Borch, C.C., Christie-Blick, N. and Grady, A.E., 1988. Depositional sequence analysis applied to Late Proterozoic Wilpena Group, Adelaide Geosyncline, South Australia. Aust. J. Earth Sci., 35: 59-71.

Von der Borch, C.C., Grady, A.E., Eickhoff, K.H., DiBona, P. and Christie-Blick, N., 1989. Late Proterozoic Patsy Springs canyon, Adelaide Geosyncline: submarine or subaerial origin? Sedimentology, 36: 777-792.

Walker, R.G., 1992. Turbidites and submarine fans. In: R.G. Walker and N.P. James (Editors), Facies Models. Response to Sea Level Change. Geological Association of Canada, St. John's, Nfld., pp. 239-263

Walker, R.G. and Plint, A.G., 1992. Wave- and storm-dominated shallow marine systems. In: R.G. Walker and N.P. James (Editors). Facies Models. Response to Sea Level Change. Geological Association of Canada, St. John's, Nfld., pp. 219-238.

Walter, M.R., Elphinstone, R. and Heys, G.R., 1989. Proterozoic and Early Cambrian trace fossils from the Amadeus and Georgina Basins, central Australia. Alcheringa, 13: 209-256.

Walter, M.R., Veevers, J.J., Calver, C.R. and Grey, K., 1995. Neoproterozoic stratigraphy of the Centralian Superbasin, Australia.
In: A.H. Knoll and M. Walter (Editors), Neoproterozoic Stratigraphy and Earth History. Precambrian Res., 73: 173-195 (this volume).

Webb, A.W. and Coats, R.P., 1980. A reassessment of the age of the Beda Volcanics on the Stuart shelf, South Australia. South Aust. Dep. Mines Energy, Rep. 80/6 (unpubl.).

Wheeler, H.E., 1958. Time-stratigraphy. Am. Assoc. Pet. Geol. Bull., 42: 1047-1063.

Williams, G.E., 1979. Sedimentology, stable-isotope geochemistry and palaeoenvironment of dolostones capping late Precambrian glacial sequences in Australia. J. Geol. Soc. Aust., 26: 377-386.

Xing Yusheng, 1992. Geologic guide booklets to stratotypes of Sinian and Cambrian section in Yichang, Hubei. Geol. Mus. China, Beijing.

Young, G.M., 1979. Correlation of middle and upper Proterozoic strata of the northern rim of the North Atlantic craton. R. Soc. Edinburgh Trans., 70: 323-336.

Young, G.M. and Gostin, V.A., 1988. Stratigraphy and sedimentology of Sturtian glacigenic deposits in the western part of the north Flinders Basin, South Australia. Precambrian Res., 39: $151-170$.

Young, G.M. and Gostin, V.A., 1989a. Depositional environment and regional stratigraphic significance of the Serle Conglomerate: a Late Proterozoic submarine fan complex, South Australia. Palaeogeogr., Palaeoclimatol., Palaeoecol., 71: 237-252.

Young, G.M. and Gostin, V.A., 1989b. An exceptionally thick upper Proterozoic (Sturtian) glacial succession in the Mount Painter area, South Australia. Geol. Soc. Am. Bull, 101: 834-845.

Young, G.M. and Gostin, V.A., 1990. Sturtian glacial deposition in the vicinity of the Yankaninna Anticline, North Flinders Basin, South Australia. Aust. J. Earth Sci., 37: 447-458.

Young, G.M. and Gostin, V.A., 1991. Late Proterozoic (Sturtian) succession of the North Flinders Basin, South Australia; an example of temperate glaciation in an active rift setting. In: J.B. Anderson and G.M. Ashley (Editors), Glacial Marine Sedimentation; Paleoclimatic Significance. Geol. Soc. Am. Spec. Pap., 261: 207222.

Zang, W.L. and Walter, M.R., 1989. Latest Proterozoic plankton from the Amadeus Basin in central Australia. Nature, 337: 642645.

Zang, W.L. and Walter, M.R., 1992. Late Proterozoic and Cambrian microfossils and biostratigraphy, Amadeus Basin, central Australia. Assoc. Australas. Palaeontol., Mem. 12, 132 pp.

Note added in proof. The origin of the Wonoka canyons remains a mystery. The first author favours the idea that they were cut in a subaerial environment, for reasons discussed in this paper. I.A. Dyson and C.C. von der Borch continue to entertain the possibility that there might be some way of accommodating the sedimentological and stratigraphic evidence in a deep-water model, in order to avoid the paleogeographic consequences in invoking kilometre-scale changes in base level. 